Article

\title{
Ir-Sn-Sb-O Electrocatalyst for Oxygen Evolution Reaction: Physicochemical Characterization and Performance in Water Electrolysis Single Cell with Solid Polymer Electrolyte
}

\author{
Nicté J. Pérez-Viramontes ${ }^{1}$, Virginia H. Collins-Martínez ${ }^{2}$, Ismailia L. Escalante-García ${ }^{3}$ (D), \\ José R. Flores-Hernández ${ }^{4}$, Marisol Galván-Valencia ${ }^{3}$ and Sergio M. Durón-Torres ${ }^{3, *}$ \\ 1 Electrical Engineering Department, Autonomous University of Zacatecas, Col. Centro, \\ Av. Ramón López Velarde 801, Zacatecas C.P. 98000, Mexico; nickyperezv@gmail.com \\ 2 S.C. Department of Materials Engineering and Chemistry, Advanced Materials Research Center, \\ Miguel Cervantes 120, Complejo Industrial Chihuahua C.P. 31190, Mexico; virginia.collins@cimav.edu.mx \\ 3 Chemistry Department, Autonomous University of Zacatecas, Campus Siglo XXI, Edif. 6, \\ Km 6 Carr. Zacatecas-Guadalajara, Zacatecas C.P. 98160, Mexico; ileg@uaz.edu.mx (I.L.E.-G.); \\ gavm001144@uaz.edu.mx (M.G.-V.) \\ 4 National Institute of Electric and Clean Energy, Reforma 113, Col. Palmira, Cuernavaca, \\ Morelos C.P. 62490, Mexico; jrflores@ineel.mx \\ * Correspondence: duronm@uaz.edu.mx; Tel.: +52-492-106-2933
}

Received: 31 March 2020; Accepted: 5 May 2020; Published: 8 May 2020

\begin{abstract}
Mixed oxide Ir-Sn-Sb-O electrocatalyst was synthesized using thermal decomposition from chloride precursors in ethanol. Our previous results showed that Ir-Sn-Sb-O possesses electrocatalytic activity for an oxygen evolution reaction (OER) in acidic media. In the present work, the physicochemical characterization and performance of Ir-Sn-Sb-O in an electrolysis cell are reported. $\mathrm{IrO}_{2}$ supported on antimony doped tin oxide (ATO) was also considered in this study as a reference catalyst. Scanning electron microscopy (SEM) images indicated that Ir-Sn-Sb-O has a mixed morphology with nanometric size. Energy dispersive X-ray spectroscopy (EDS) showed a heterogeneous atomic distribution. Transmission electron microscopy (TEM) analysis resulted in particle sizes of $\mathrm{IrO}_{2}$ and ATO between 3 to $>10 \mathrm{~nm}$, while the Ir-Sn-Sb-O catalyst presented non-uniform particle sizes from 3 to $50 \mathrm{~nm}$. X-ray diffraction (XRD) measurements indicated that synthesized mixed oxide consists of $\mathrm{IrO}_{2}, \mathrm{IrO}_{\mathrm{x}}$, doped $\mathrm{SnO}_{2}$ phases and metallic Ir. The Ir-Sn-Sb-O mixed composition was corroborated by temperature programmed reduction (TPR) measurements. The performance of Ir-Sn-Sb-O in a single cell electrolyser showed better results for hydrogen production than $\mathrm{IrO}_{2} /$ ATO using a mechanical mixture. Ir-Sn-Sb-O demonstrated an onset potential for water electrolysis close to $1.45 \mathrm{~V}$ on Ir-Sn-Sb-O and a current density near to $260 \mathrm{~mA}$ $\mathrm{mg}^{-1}$ at $1.8 \mathrm{~V}$. The results suggest that the mixed oxide Ir-Sn-Sb-O has favorable properties for further applications in water electrolysers.
\end{abstract}

Keywords: OER electrocatalyst; Ir-Sn-Sb-O; solid polymer electrolyte water electrolyser

\section{Introduction}

Hydrogen $\left(\mathrm{H}_{2}\right)$ production has been achieved using different processes such as hydrocarbon reforming, photocatalytic generation, biodigestion, water thermolysis and water electrolysis $[1,2]$. Water electrolysis (WE) is one of the most preferable processes since pure $\mathrm{H}_{2}$ can be obtained with the production of $\mathrm{O}_{2}$ as a secondary reaction [3]. Water electrolysis is a process in which a water molecule 
is separated into hydrogen and oxygen through the use of electrical energy. Hydrogen evolution reaction (HER) occurs at the cathode, while the evolution reaction of oxygen takes place in the anode side of a water electrolysis system [4-6]. Alkaline water electrolysis (AWE), solid oxide electrolysis (SOE) and solid polymer electrolyte water electrolysis (SPEWE) are some examples of water electrolysis systems currently available [7]. AWE presents several advantages such as a well-established technology, use of low-cost metals as catalysts and relatively low-cost materials for the system design. However, low current densities, crossover of gases and low operational pressures are some disadvantages that are associated with AWE. SOE is an emerging technology and further research is essential to establish its future potential application. On the other hand, SPEWE is currently the most studied electrolysis process thanks to several technological features [7-10]: high current densities, high voltage efficiency, good partial load range, compact system design and high purity gas production. Nevertheless, SPEWE has drawbacks such as the high cost of its components (i.e., proton membrane exchange (PEM) and noble metal catalysts) and a restricted low range of output power. In general, water electrolysis requires an excess of energy (i.e., overpotential) to overcome activation barriers, and without a proper supply of this energy excess, hydrogen and oxygen are produced slowly [11].

In WE, HER occurs near its thermodynamic potential with a rapid rate [12]. In contrast, the determining step in WE is the oxygen evolution reaction (OER). This is an irreversible reaction that commonly requires the application of a high overpotential in order to succeed. In order to reduce the power requirement of OER, several electrocatalysts have been proposed. In acidic media, it has been found that oxides of ruthenium and iridium with a rutile structure present high electrocatalytic activity for this reaction [4-6,13-16]. However, these are metals of low abundance in the earth's crust; thus, their use considerably increases the overall cost of a water electrolyser when using these materials. In addition, $\mathrm{RuO}_{2}$ is unstable and dissolves at the operating potentials of SPEWE [5,13,17-19]. Accordingly, it is essential to obtain new lower-cost materials that catalyse the OER and present electrochemical, mechanical and thermal stability at the usual electrolyser operating conditions. A common practice that deserves attention and more research is the addition of supports and/or dopant elements in order to achieve low-load and stable catalysts with synergistic effects that speed up the oxygen evolution reaction [20-25]. Antimony doped tin oxide (ATO) has been used in multiple electrochemical applications, for instance, in fuel cells, batteries, gas sensors, solar cells, etc. [23,26]. Recently, ATO has been studied as a support for catalysts in WE due to its corrosion resistance properties in acidic media [21]. Likewise, $\mathrm{SnO}_{2}-\mathrm{IrO}_{2}$ mixtures have been extensively researched as electrocatalysts for the OER in an acidic environment $[16,27,28]$.

Synthesis methods to obtain multi-element metallic materials have been investigated in order to reduce the load of precious metal in the anode design without compromising their electrocatalytic activity by their dilution [29-35]. Mixed oxides synthesized by thermal decomposition have shown high activity for OER [36-38]. However, the preparation of electrodes using this technique generally involves the use of a metallic substrate (i.e., titanium plates), and as a consequence, an adequate electrical contact between the electrode and the electrolyte membrane in the SPEWE is limited. As an alternative approach, the development of catalyst-support composite in powdered form can be proposed in order to improve the electrical contact between materials in the membrane electrode assembly (MEA) of SPEWE. In this context, our research group has previously reported a half-cell study of a mixed oxide Ir-Sn-Sb-O that demonstrated catalytic activity for OER [39]. In this early study, the oxide with Ir at $40 \%$ atomic composition showed superior electrocatalytic activity for OER compared with the mechanical mixed $\mathrm{IrO}_{2}$ /ATO.

In order to further explore the properties and potential application of Ir-Sn-Sb-O mixed oxide, in this paper a detailed characterization and the preliminary performance of Ir-Sn-Sb-O in a single cell electrolyser are reported. For comparison purposes, mechanical mixtures of $\mathrm{IrO}_{2}$ and $\mathrm{ATO}\left(\mathrm{IrO}_{2} / \mathrm{ATO}\right)$ were used as a reference and characterized using the same techniques. All electrocatalytic materials were obtained by thermal decomposition of the chloride precursors in ethanol using a synthesis procedure previously reported [39]. The morphology, structure and composition of electrocatalysts 
were analyzed using the following techniques: SEM, EDS, TEM, XRD and TPR. In order to get additional information about the materials, electrical conductivity was calculated from resistivity measurements by using a four points electrical resistivity (ER) device.

In general, the results showed that the polarisation curves for both catalysts are consistent with electrochemical impedance spectroscopy (EIS) results and other electrochemical measurements. These results indicate that Ir-Sn-Sb-O has better OER electrocatalytic properties than $\mathrm{IrO}_{2} / \mathrm{ATO}$. Remarkably, the Ir-Sn-Sb-O material has the advantage of being obtained through a one-pot reaction, which is of great importance because the synthesis time was considerably reduced. For OER in $\mathrm{WE}$, the measured onset potential was close to $1.45 \mathrm{~V}$, and a current density of $300 \mathrm{~mA}$ per mg of Ir was recorded at a potential of $2.0 \mathrm{~V}$ for non-optimized single electrolysis cell measurements. The physicochemical and electrochemical results confirm that Ir-Sn-Sb-O electrocatalyst material could be used as anode in commercial WE devices.

\section{Results and Discussion}

\subsection{Physical and Chemical Properties}

\subsubsection{Electrical Conductivity}

The electrical conductivity, $\sigma$, of the materials was evaluated at different powder compaction pressures, $\mathrm{P}$, using a four-points probe in a cylinder-piston device. The obtained conductivity values are reported in Table 1. The $\sigma$ of the materials decreases as $\mathrm{Ir}-\mathrm{Sn}-\mathrm{Sb}-\mathrm{O}>\mathrm{IrO}_{2}>$ ATO, as shown in Table 1 . The higher electrical conductivity observed for Ir-Sn-Sb-O may be due to the presence of metallic iridium and to the doping of mixed oxide with antimony, which improves the electron transport through the material. At 150 psi of pressure, the Ir-Sn-Sb-O material presented an electrical conductivity of $158,000 \mathrm{~S} \mathrm{~m}^{-1}$ approximately. This is a higher conductivity value than that for the $308 \mathrm{~S} \mathrm{~m}^{-1}$ mean value obtained for ATO. At the same time, the $\sigma$ of Ir-Sn-Sb-O is several magnitude orders higher than typical conductivity values reported for Vulcan carbon $\left(2160 \mathrm{~S} \mathrm{~m}^{-1}\right)$, ATO $\left(29.5 \mathrm{~S} \mathrm{~m}^{-1}\right)$ and $\mathrm{SnO}_{2}\left(0.17 \mathrm{~S} \mathrm{~m}^{-1}\right)$, obtained using four-points probe measurements in pellets at high compaction pressure [40]. For the $\mathrm{IrO}_{2}$ synthetized by thermal decomposition, the $\sigma$ value $\left(>1 \times 10^{5} \mathrm{~S} \mathrm{~m}^{-1}\right)$ was lower than the value reported for the mixed oxide; however, this value is consistent with the metallic conductivity commonly observed in iridium oxides [38,41]. Although a true comparison of conductivity with literature data is difficult to make due to the different experimental approaches used, the synthesized mixed oxide obtained appears to be a better electronic conductor than commonly used supports. These results suggest that the one pot synthesis method used in this work and the interaction of different metal oxides promotes the electronical conductivity of material. In Table 1, note that for all the materials, $\sigma$ increases as the applied pressure increases. This observation is consistent with the progressive compaction of the powder by the piston in the measurement system, enhancing, then, the physical contact between the particles, and as a result, higher electrical conductivity values were obtained.

Table 1. Electrical conductivity of the synthesized materials at different pressures values.

\begin{tabular}{cccc}
\hline \multirow{2}{*}{$\mathbf{P} / \mathbf{p s i}$} & $\mathbf{I r - S n - S b - O}$ & $\mathbf{I r O}_{\mathbf{2}}$ & ATO $^{\mathbf{a}}$ \\
\cline { 2 - 4 } & \multicolumn{3}{c}{$\boldsymbol{\sigma} / \mathbf{S ~ m}^{\mathbf{- 1}}$} \\
\hline 0 & $11,163 \pm 715$ & $252 \pm 16$ & $3.6 \pm 0.5$ \\
50 & $87,447 \pm 16,179$ & $22,191 \pm 1681$ & $6.4 \pm 0.5$ \\
100 & $122,620 \pm 6688$ & $42,788 \pm 2609$ & $175 \pm 34$ \\
150 & $157,981 \pm 15,418$ & $87,236 \pm 6618$ & $308 \pm 48$ \\
200 & $270,037 \pm 24,019$ & $145,357 \pm 23,769$ & $559 \pm 52$ \\
\hline
\end{tabular}

a: antimony doped tin oxide. 


\subsubsection{Scanning Electron Microscopy}

Figure 1 shows the SEM micrographs of the ATO, $\mathrm{IrO}_{2}$ and $\mathrm{Ir}-\mathrm{Sn}-\mathrm{Sb}-\mathrm{O}$ materials. Figure 1a corresponds to a micrograph of ATO with a 50,000 $\times$ magnification, and it can be seen that the material is composed of agglomerates of particles with an average size of $50 \mathrm{~nm}$. A higher magnification micrograph, 200,000x, shown in Figure 1b, reveals that the ATO support is composed of globular particles with sizes close to $10 \mathrm{~nm}$. In Figure $1 \mathrm{c}, \mathrm{d}$, it is possible to appreciate that $\mathrm{IrO}_{2}$ exhibits a more homogeneous morphology; in this case, nanometric $\mathrm{IrO}_{2}$ particles showed less agglomeration than ATO particles and the micrograph at 200,000 $\times$ magnification, Figure 1d, corroborated a near-to-spherical morphology of iridium oxide. In contrast, the Ir-Sn-Sb-O micrographs (Figure 1e,f) show a heterogeneous morphology composed of low porosity, large laminar aggregates with a size up to $600 \mathrm{~nm}$ and smaller agglomerates composed of fine globular particles. The high magnification SEM image suggests that Ir-Sn-Sb-O particles have particle sizes less than $10 \mathrm{~nm}$, as shown in Figure 1f. The results of the chemical composition analysis using EDS and chemical elements distribution are discussed below.

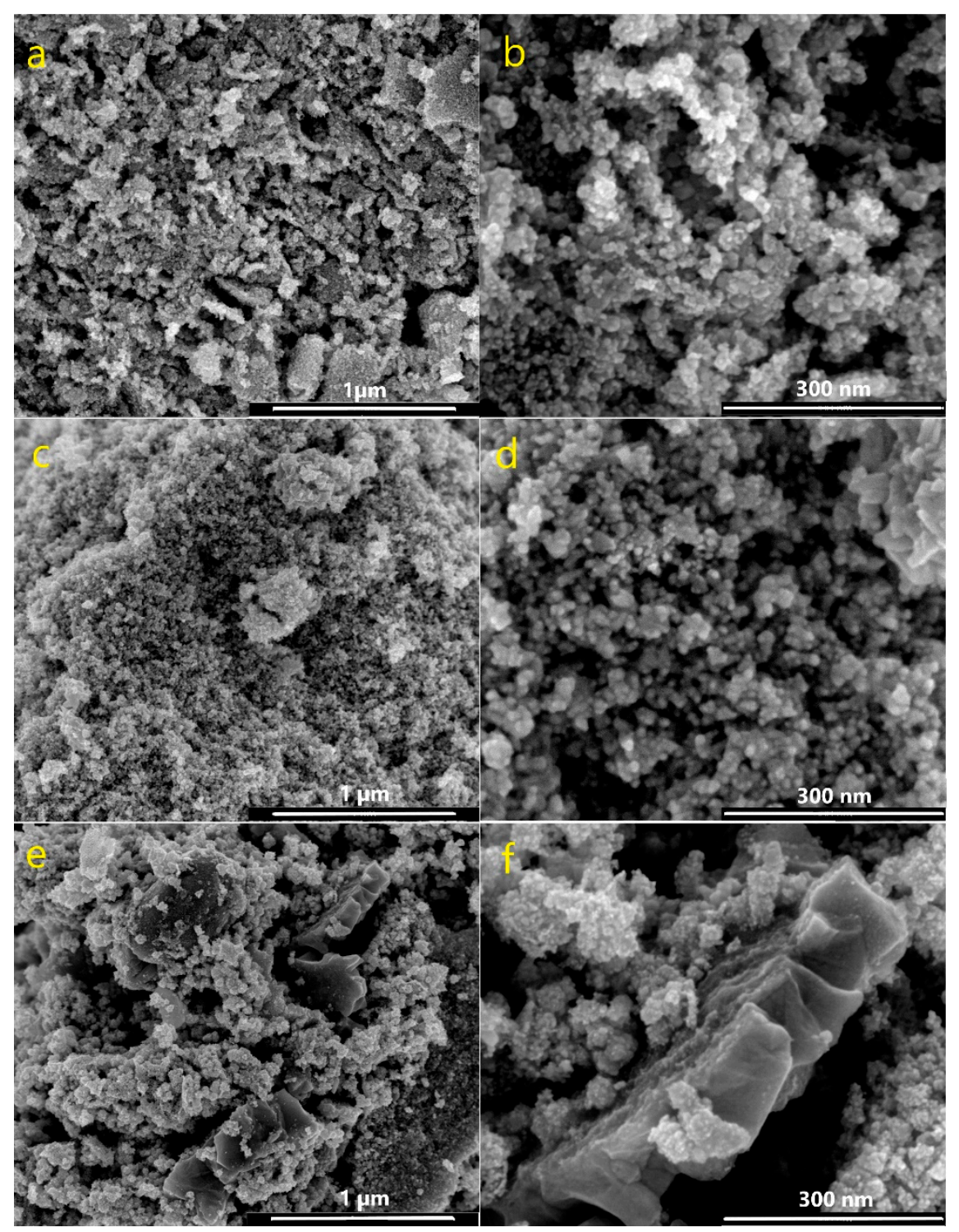

Figure 1. SEM micrographs of ATO: (a) 50,000× and (b) 200,000×. $\mathrm{IrO}_{2}$ : (c) 50,000× and (d) 200,000×. Ir-Sn-Sb-O: (e) 50,000x and (f) 200,000x. 


\subsubsection{Transmission Electron Microscopy}

TEM micrographs of ATO are shown in Figure 2. Scanning-transmission electron microscopy (STEM) bright field mode micrographs displayed that the material is a polydisperse system of globular particles, as shown in Figure 2a. From image analysis of Figure 2b, STEM dark field mode, the histogram shown as an insert was obtained. It can be observed here that ATO nanoparticles show sizes between $3 \mathrm{~nm}$ to $>10 \mathrm{~nm}, 5 \mathrm{~nm}$ and $7 \mathrm{~nm}$ being the sizes with the most abundant frequencies. Figure $2 \mathrm{c}$ shows the highest magnification micrograph, where the globular shape of the particles is confirmed. In some micrograph areas it is possible to distinguish the crystalline planes of the material. Although most of the particles have sizes smaller than $10 \mathrm{~nm}$, a small fraction of them exceeds this size. Furthermore, some dislocations and deflections can be appreciated in the planes, which could be associated with the doping of $\mathrm{SnO}_{2}$ with $\mathrm{Sb}$. Interplanar distances are determined in Figure 2d. The evaluated distances of $2.36 \AA$ and $3.34 \AA$ are associated with (200) and (110) planes of $\mathrm{SnO}_{2}$ with a rutile structure, and the (110) plane is predominantly across this oxide. Ávila Vázquez et al. [42] reported a d-spacing of $3.34 \AA$ for the (110) plane for the $\mathrm{Sb}$ doped tin oxide, therefore tin oxide synthesized in this work may be considered as doped by Sb. The presence of these planes was further supported by XRD results.

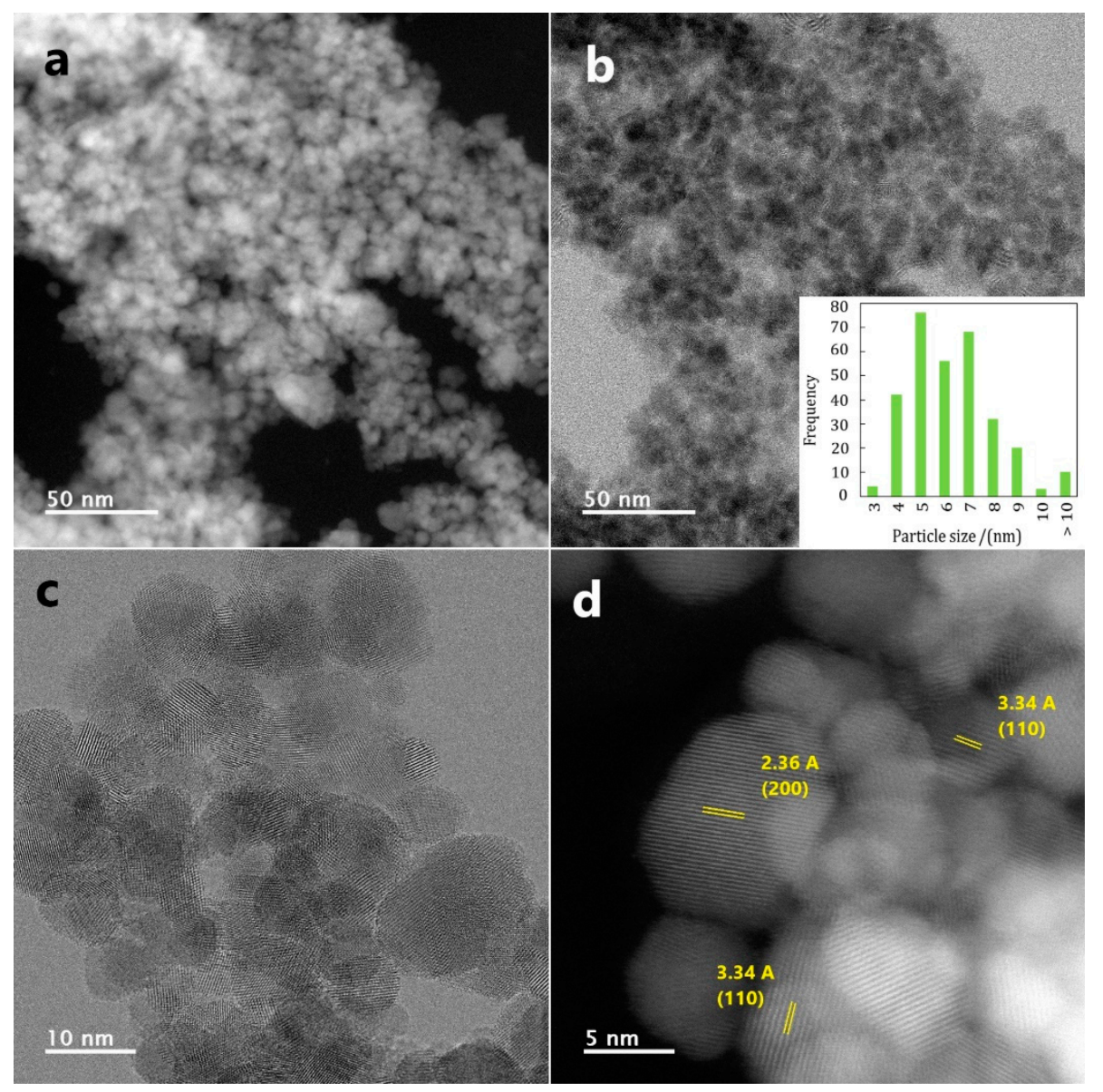

Figure 2. TEM images of ATO (a) STEM bright field mode, (b) STEM dark field image, in the insert: particle size distribution, $(\mathbf{c}, \mathbf{d})$ high resolution transmission electron microscopy (HRTEM) images of nanoparticles.

TEM micrographs of the $\mathrm{IrO}_{2}$ are shown in Figure 3. A globular shape and dispersion of oxide particles are observed in the STEM bright field micrographs (Figure 3a). Particle size distribution analysis was obtained from Figure $3 b$, and the corresponding histogram is shown as an insert. Measured particles sizes ranged from $3 \mathrm{~nm}$ to particles greater than $10 \mathrm{~nm}$; the major frequencies were observed between 5 to $7 \mathrm{~nm}$. The shape of the nanoparticles is mainly globular (Figure 4c). Interplanar distances 
were obtained from the high resolution micrograph in Figure $3 \mathrm{~d}$, and spacings of $2.58 \AA$ and $3.18 \AA$ were attributed to (101) and (110) planes, respectively, of rutile structure $\mathrm{IrO}_{2}$.

TEM micrographs of Ir-Sn-Sb-O are shown in Figure 4. The STEM bright field micrograph in Figure 4a reveals highly dispersed nanosized particles that are deposited on the surface of micrometric size particles. In addition, the particles are agglomerated in large clusters. From Figure $4 b$, it was possible to obtain the histogram of the particle size distribution. The smaller particles have sizes between 2 to $9 \mathrm{~nm}$, although larger particles with sizes $>100 \mathrm{~nm}$ could be observed. Figure $4 \mathrm{c}$ shows TEM micrographs at high resolution. EDS coupled with TEM indicated that Area 1 shown in Figure 4c (larger particles) corresponds to ATO composition, while Area 2 (smaller particles) corresponds to $\mathrm{IrO}_{2}$ composition. In Figure $4 \mathrm{~d}$ an interplanar distance of $2.2 \AA$ is observed for smaller particles. This distance could be associated with an $\mathrm{IrO}_{2}$ plane with a rutile structure or with $\operatorname{Ir}^{0}$ with a simple cubic structure. This result could indicate the existence of multiple Ir oxidation states.

Three regions of each sample were analyzed using EDS, and typical atomic percent compositions of the elements are shown in Table 2. The ATO analysis shows the presence of $\mathrm{Sn}, \mathrm{O}$ and $\mathrm{Sb}$. In two regions (referred to as Area 2 and Area 3), a Sn:O atomic ratio of 1:2 is observable; thus, it is suggested that the main synthesized oxide is $\mathrm{SnO}_{2}$. However, a $\mathrm{Sn}: \mathrm{O}$ ratio of 1:1 is also observed in the third region, which may be related with the presence of non-stoichiometric oxides. Likewise, a small percentage of $\mathrm{Sb}$ is present in two regions. This low atomic percentage is consistent with antimony as a doping species. On the other hand, the varying Ir:O atomic ratios found in $\mathrm{IrO}_{2}$, suggest the formation of different oxides in the catalyst, and they may be related with the presence of non-stoichiometric iridium oxide.

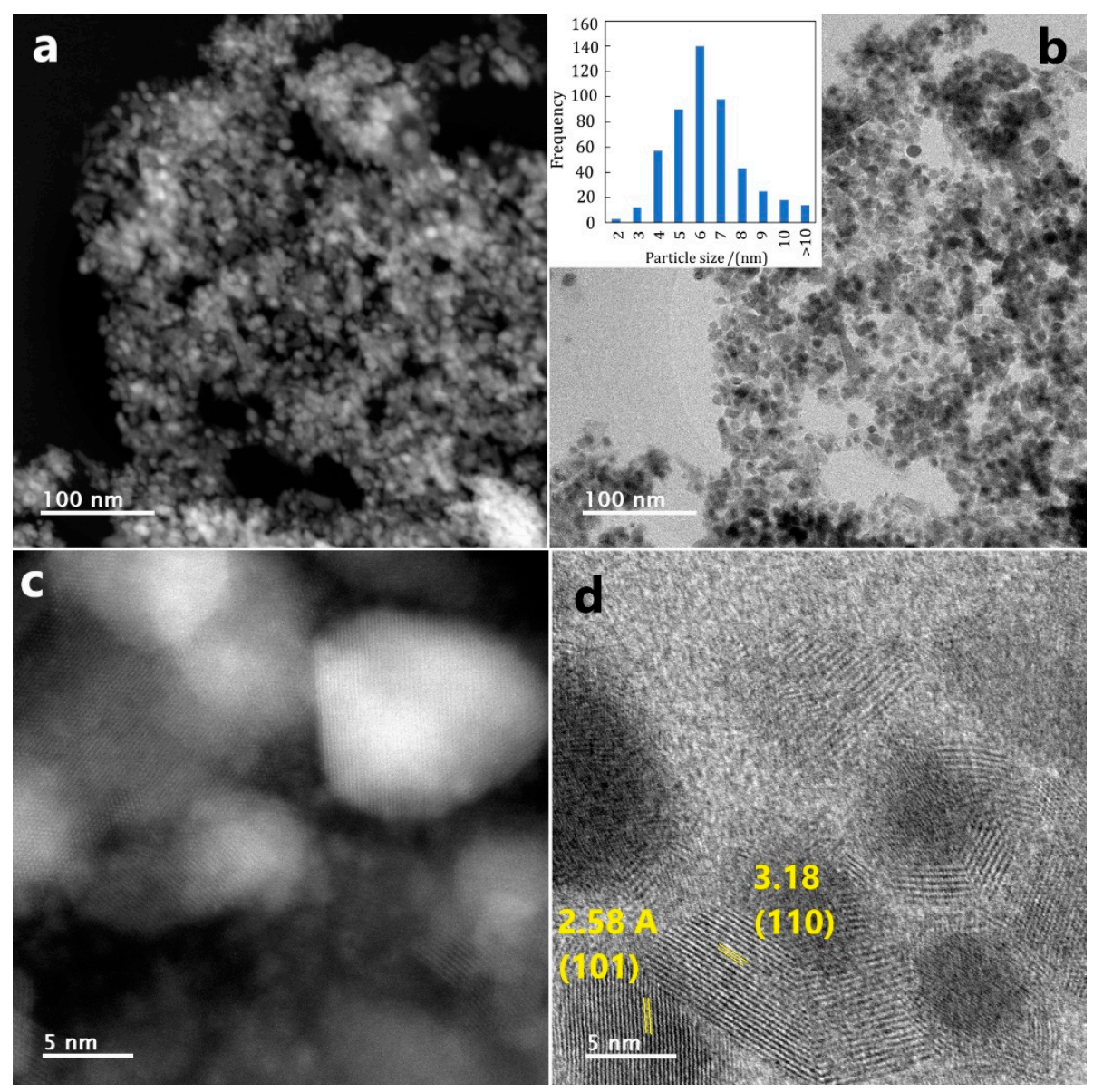

Figure 3. TEM images of $\mathrm{IrO}_{2}$ (a) STEM bright field mode, (b) STEM dark field image, insert: particle size distribution, (c,d) HRTEM images of nanoparticles. 


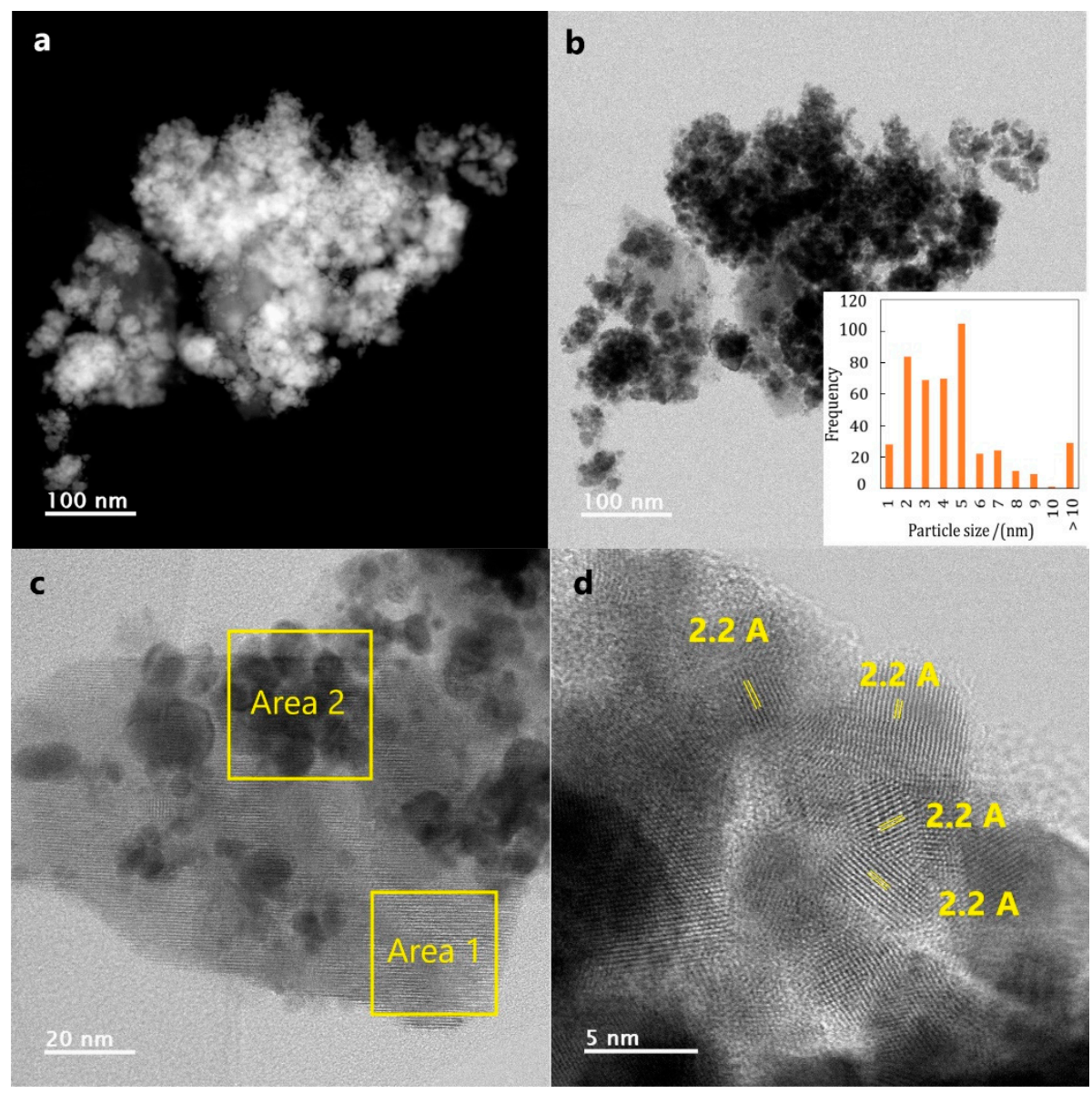

Figure 4. TEM images of Ir-Sn-Sb-O (a) STEM bright field mode, (b) STEM dark field image, insert: particle size distribution (c) TEM micrographs of nanoparticles, insert: selected areas for EDS analysis, (d) HRTEM images of nanoparticles, show the $\mathrm{d}$ spacing lattice.

Table 2. EDS analysis for three selected areas for ATO, $\mathrm{IrO}_{2}$ and $\mathrm{Ir}-\mathrm{Sn}-\mathrm{Sb}-\mathrm{O}$ materials.

\begin{tabular}{ccccccc}
\hline \multirow{2}{*}{ Catalyst } & Area & Ir & O & Sn & Sb & Cl \\
\cline { 2 - 7 } & & \multicolumn{5}{c}{ Element/at. \% } \\
\hline \multirow{3}{*}{ ATO } & 1 & - & 53.28 & 44.55 & 2.17 & - \\
& 2 & - & 66.23 & 31.13 & 2.64 & - \\
\hline \multirow{2}{*}{ IrO$_{2}$} & 3 & - & 69.45 & 30.55 & 0 & - \\
& 1 & 22.74 & 71.24 & - & - & 6.02 \\
& 2 & 45.1 & 52.17 & - & - & 2.73 \\
\multirow{2}{*}{ Ir-Sn-Sb-O } & 3 & 17.65 & 79.86 & - & - & 2.49 \\
& 1 & 0 & 74.17 & 22.68 & 3.15 & 0 \\
& 2 & 26.72 & 57.34 & 6.87 & 7.4 & 1.67 \\
& 3 & 39.15 & 43.18 & 9.93 & 4.78 & 2.96 \\
\hline
\end{tabular}

The analyzed areas of the Ir-Sn-Sb-O catalyst reveal the presence of $\mathrm{Ir}, \mathrm{Sn}, \mathrm{Sb}$ and $\mathrm{O}$. Area 1 corresponds to one of the largest particles found in TEM, as previously described in Figure 4c. Here, the presence of Ir was not observable, confirming that the larger particles correspond to tin oxide; again, the low atomic percentage of $\mathrm{Sb}$ suggests that $\mathrm{SnO}_{2}$ is doped with $\mathrm{Sb}$. In Area 2, corresponding to small particles, the atomic ratio between metal and oxygen is 2:1, which corresponds to $\mathrm{IrO}_{2}$ composition. However, the atomic percentage of the elements in Area 3 indicates that the formed oxide is non-stoichiometric. Thus, the EDS results of Ir-Sn-Sb-O suggest that the surface composition of the catalyst is heterogeneous and corresponds to a mixture of multiple iridium oxides dispersed on 
$\mathrm{Sb}$ doped tin oxide. The $\mathrm{Cl}$ atoms found in EDS analyses are attributed to the presence of precursor residues. In addition, the atomic percentage of Ir was expected to be 40 at.\% Ir for Ir-Sb-Sn-O (according to the precursor proportions used in the synthesis step described in the Materials and Methods ection); however, the EDS results indicate that the average iridium atomic percentage was 33 at. $\%$ Ir in the Ir-Sb-Sn-O material, which is equivalent to a $20 \mathrm{wt}$.\% Ir. This value was used to calculate the catalyst load in the anode of the electrolyser.

\subsubsection{X-ray Diffraction}

The X-ray powder diffractograms of ATO, $\mathrm{IrO}_{2}$ and Ir-Sn-Sb-O materials are shown in Figure 5. It can be appreciated that the three oxides present a crystalline structure typical of small size crystallite materials. Figure 5 a displays the diffraction pattern of ATO, which is compared with the $\mathrm{SnO}_{2}$ reference pattern (JCPDS 14-1445). The diffractogram shows multiple peaks at $27.8^{\circ}, 33.9^{\circ}, 38.1^{\circ}, 52.46^{\circ}, 55.28^{\circ}$, $61.78^{\circ}, 67^{\circ}$ and $72.2^{\circ}$, which are associated with (110), (101), (200), (211), (220), (310) and (301) $\mathrm{SnO}_{2}$ planes respectively. These diffraction angles are related to a rutile structure of the oxide. The small displacement observed in the ATO diffraction peaks in respect to those of reference, suggest again that tin oxide is doped with antimony. The XRD pattern of the $\mathrm{IrO}_{2}$ (Figure $5 \mathrm{~b}$ ) showed intense peaks at $2 \theta$ values of $26.02^{\circ}, 34.96^{\circ}, 53.42^{\circ}, 58.1^{\circ}, 65.52^{\circ}$ and $72.48^{\circ}$, which are in good agreement with the pattern of JCPDS 15-0870 crystallographic card and attributed to the diffraction of (110), (101), (221), (002), (310) and (202) planes of $\mathrm{IrO}_{2}$ with a rutile structure, respectively [43]. Additionally, the peak observed at $47.74^{\circ}$ is associated with the (200) plane of metallic Ir, with a cubic structure (JCPDS 46-1044). The broad diffraction peak at $40.64^{\circ}$ is associated with the overlapping between the diffraction of the (200) and (111) planes of the $\mathrm{IrO}_{2}$ and the (111) plane of Ir. Similarly, the peak at $69.04^{\circ}$ corresponds to the overlapping of the (301) plane of the $\mathrm{IrO}_{2}$ and (220) plane of Ir. The slight displacements appreciated in the $\mathrm{IrO}_{2}$ diffractogram in respect to the reference cards can be attributed to the presence of Ir or other non-stoichiometric iridium oxides that could result in X-ray diffraction changes. Thus, the XRD results prove that synthesized $\mathrm{IrO}_{2}$ is mainly a mixture of metallic Ir and iridium oxide phases. Finally, Figure $5 \mathrm{c}$ shows the XRD diffraction pattern of Ir-Sn-Sb-O. In this diffractogram, the presence of peaks is observed at $27.54^{\circ}, 33.82^{\circ}, 37.88^{\circ}, 51.96^{\circ}, 54.76^{\circ}, 57.76^{\circ}, 61.77^{\circ}$, $64.58^{\circ}, 65.88^{\circ}$ and $69.12^{\circ}$, corresponding as before to diffraction angles of the $\mathrm{SnO}_{2}$ rutile structure, as previously discussed. Again, the peaks at $40.62^{\circ}$ and $47.2^{\circ}$ can be associated with cubic structured metallic Ir. In this catalyst it was not possible to identify any diffraction peak related with $\mathrm{IrO}_{2}$; however, the presence of amorphous $\mathrm{IrO}_{x}$ cannot be discarded, since it does not commonly present a defined XRD pattern [44]. Furthermore, TPR measurements could confirm the presence of this species.

\subsubsection{Temperature Programmed Reduction}

TPR profiles of commercial $\mathrm{SnO}_{2}$ and synthesized ATO are shown in Figure 6a, and the TPR profiles of ATO, $\mathrm{IrO}_{2}$ and $\mathrm{Ir}-\mathrm{Sn}-\mathrm{Sb}-\mathrm{O}$ are reported in Figure $6 \mathrm{~b}$. Note that the thermal conductivity detector (TCD) signal for Figure 6a,b was normalized by the sample mass. The reduction profile of $\mathrm{SnO}_{2}$ is symmetric with a maximum of $850 \mathrm{~K}$; this signal suggests that the $\mathrm{SnO}_{2}$ suffers an easy reduction by $\mathrm{H}_{2}$. The TPR profile of ATO has a maximum at the same temperature, suggesting that the main oxide corresponds to $\mathrm{SnO}_{2}$. Furthermore, the slight asymmetry observed and the presence of a small peak near to $1100 \mathrm{~K}$ have been reported as evidence for the $\mathrm{Sb}$ doping of $\mathrm{SnO}_{2}$ [45]. In Figure 6b, TPR profiles are shown for $\mathrm{IrO}_{2}$ and $\mathrm{Ir}-\mathrm{Sn}-\mathrm{Sb}-\mathrm{O}$ catalyst, and they are also compared with those for $\mathrm{SnO}_{2}$. In the $\mathrm{IrO}_{2}$ reduction, two stages are observed as described next. A first reduction peak starts near to $400 \mathrm{~K}$ reaching a maximum value at $450 \mathrm{~K}$; this peak is associated with the amorphous phase of iridium oxide $\left(\mathrm{IrO}_{\mathrm{x}}\right)$ [44]. A second reduction peak appears close to $550 \mathrm{~K}$ and is associated with the reduction of the $\mathrm{IrO}_{2}$ with a rutile structure [44]. On the other hand, the Ir-Sn-Sb-O TPR curve shows multiple reduction peaks, with the first appearing near to $500 \mathrm{~K}$, which likewise is associated with the reduction of $\mathrm{IrO}_{\mathrm{x}}$. A displacement in the maximum of the reduction peak can be observed with respect to that obtained for $\mathrm{IrO}_{2}$, and it is associated with an improvement of the thermal stability of the oxide 
due to the interaction with other metal oxides. Similarly, a shoulder near to $550 \mathrm{~K}$ is observable and corresponds to the reduction of $\mathrm{IrO}_{2}$. Broad reduction peaks of $\mathrm{SnO}_{2}$ species can also be appreciated between 700 and $800 \mathrm{~K}$. The TPR results along with the EDS and XRD results confirm that Ir-Sn-Sb-O catalyst consists of a mixture of multiple phases, with different oxidations states of Ir which could interact with each other to favor the electrocatalysis of OER.

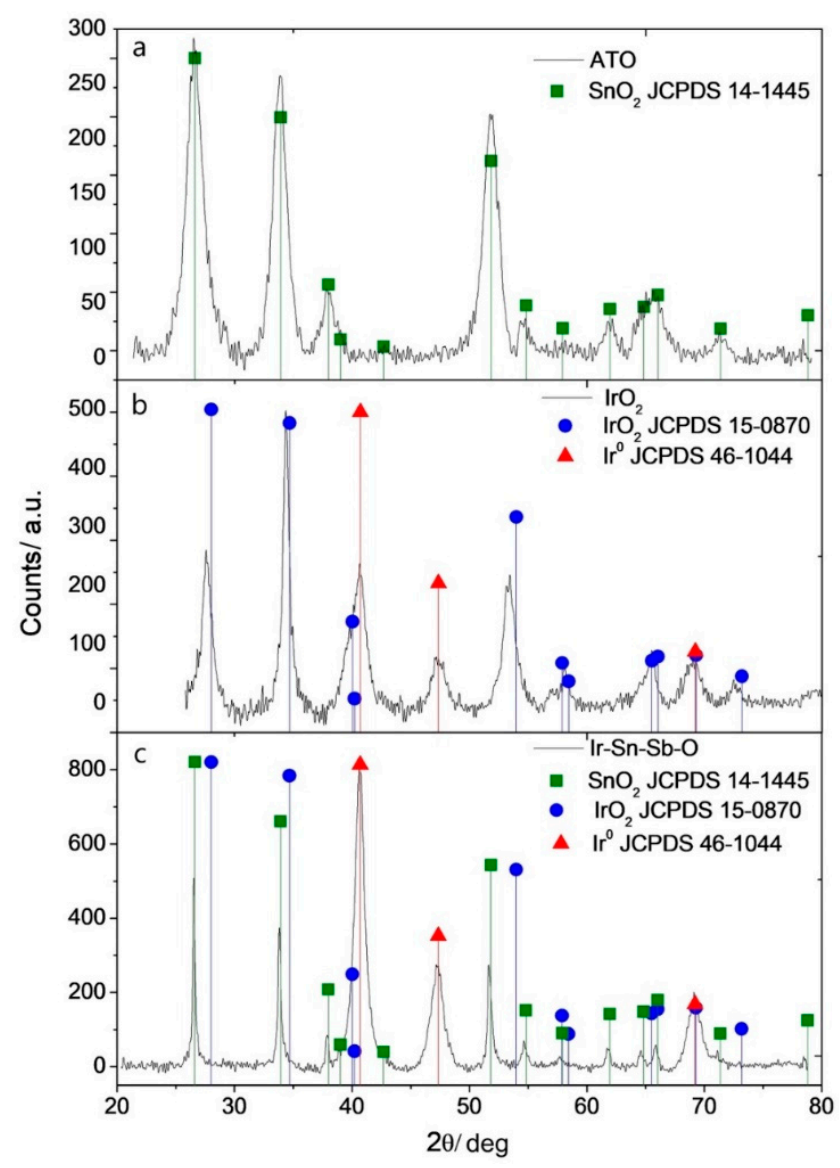

Figure 5. X-ray diffraction patterns of (a) ATO, (b) $\mathrm{IrO}_{2}$ and (c) $\mathrm{Ir}-\mathrm{Sn}-\mathrm{Sb}-\mathrm{O}$.
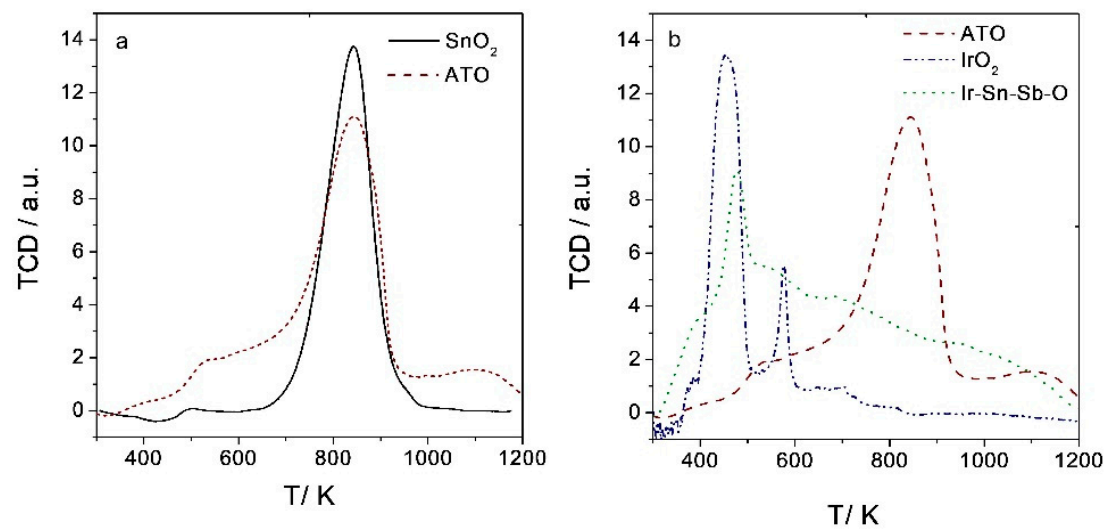

Figure 6. TPR profile of (a) commercial $\mathrm{SnO}_{2}(-)$ and ATO (- - -) and (b) ATO (- - -), $\mathrm{IrO}_{2}(-\cdots)$ and $\mathrm{Ir}-\mathrm{Sn}-\mathrm{Sb}-\mathrm{O}(\cdots)$ at $10{ }^{\circ} \mathrm{C} \mathrm{min}^{-1}$ heating rate.

\subsection{Single Cell Electrochemistry}

All electrochemical experiments in single electrolysis cell were carried out at $70{ }^{\circ} \mathrm{C}$ with a flow rate of water of $7 \mathrm{~mL} \mathrm{~min}^{-1}$. The total resistance of the cell was measured by using a high impedance 
ohmmeter, showing a low resistance of $0.24 \Omega$. The single-cell experiments were performed for comparative purposes between Ir-Sn-Sb-O and $\mathrm{IrO}_{2} / \mathrm{ATO}$ catalysts using a potentiostat/galvanostat. In the electrochemical graphics shown in this section, the current density is normalized by the Ir metal mass used in the anode, and all the potentials reported in the paper correspond to the cell voltage ( $\left.\mathrm{E}_{\text {cell }}\right)$, which is the terminal potential applied between the cathode and anode, usually is represented as:

$$
E_{\text {cell }}=\frac{\Delta G(T, p)}{2 F}+\eta_{A}^{a}(j)+\left|\eta_{A}^{c}(j)\right|+j \sum R_{\text {cell }}
$$

where $\frac{\Delta G(T, p)}{2 F}$ is the thermodynamic voltage of water electrolysis, $\eta_{A}^{a}$ and $\left|\eta_{A}^{c}\right|$ are the anodic and cathodic overvoltages, and $R_{\text {cell }}$ is the global ohmic resistance of the cell $[46,47]$.

A commercial catalyst of $\mathrm{Pt} / \mathrm{C}$ at $5 \mathrm{wt} . \%$ was used as cathode, with a load of $0.2 \mathrm{mg} \mathrm{cm}^{-2}$ of Pt. At the anode side, Ir-Sn-Sb-O or $\mathrm{IrO}_{2} / \mathrm{ATO}$, was used with a load of $2.6 \mathrm{mg} \mathrm{cm}^{-2}$ equivalent to $0.5 \mathrm{mg} \mathrm{cm}^{-2}$ of Ir metal, as estimated from EDS measurements. The catalysts were sprayed on both sides of a Nafion ${ }^{\circledR} 117$ membrane. Further details of the electrolysis cell and MEA preparation can be found in the Materials and Methods section.

\subsubsection{Cyclic Voltammetry}

Cyclic voltammetry $(\mathrm{CV})$ of $\mathrm{IrO}_{2} / \mathrm{ATO}$ and Ir-Sn-Sb-O MEAs obtained before the polarization curves are shown in Figure 7a. It can be observed that the onset potential for the OER ( $\left.E_{\mathrm{OER}}\right)$ starts near to $1.5 \mathrm{~V}$ for assemblies with $\mathrm{IrO}_{2} / \mathrm{ATO}$ or Ir-Sn-Sb-O catalysts. Nevertheless, the electrolysis reaction on the Ir-Sn-Sb-O occurs faster than on the $\mathrm{IrO}_{2} / \mathrm{ATO}$ assembly. For instance, at $1.8 \mathrm{~V}$ the current density is approximately $70 \mathrm{~mA} \mathrm{mg}^{-1}$ for ATO supported iridium oxide and close to $130 \mathrm{~mA} \mathrm{mg}^{-1}$ for Ir-Sn-Sb-O catalyst. In Figure $7 b$, the CV of Ir-Sn-Sb-O and $\mathrm{IrO}_{2} / \mathrm{ATO}$ are shown after the polarization curve, and a decrease in the electroactivity of both assemblies can be appreciated. The decrease in the current density for both materials could be due to a dissolution of the coating on the membrane surface, but further experimentation should be done to prove it. However, the fall in the current density for Ir-Sn-Sb-O in the CV was close to $30 \%$ of the initial current density, while the $\mathrm{IrO}_{2} / \mathrm{ATO}$ assembly exhibited a drop near to $40 \%$. Overall, these results may be interpreted as the first evidence of an increased stability of Ir-Sn-Sb-O.
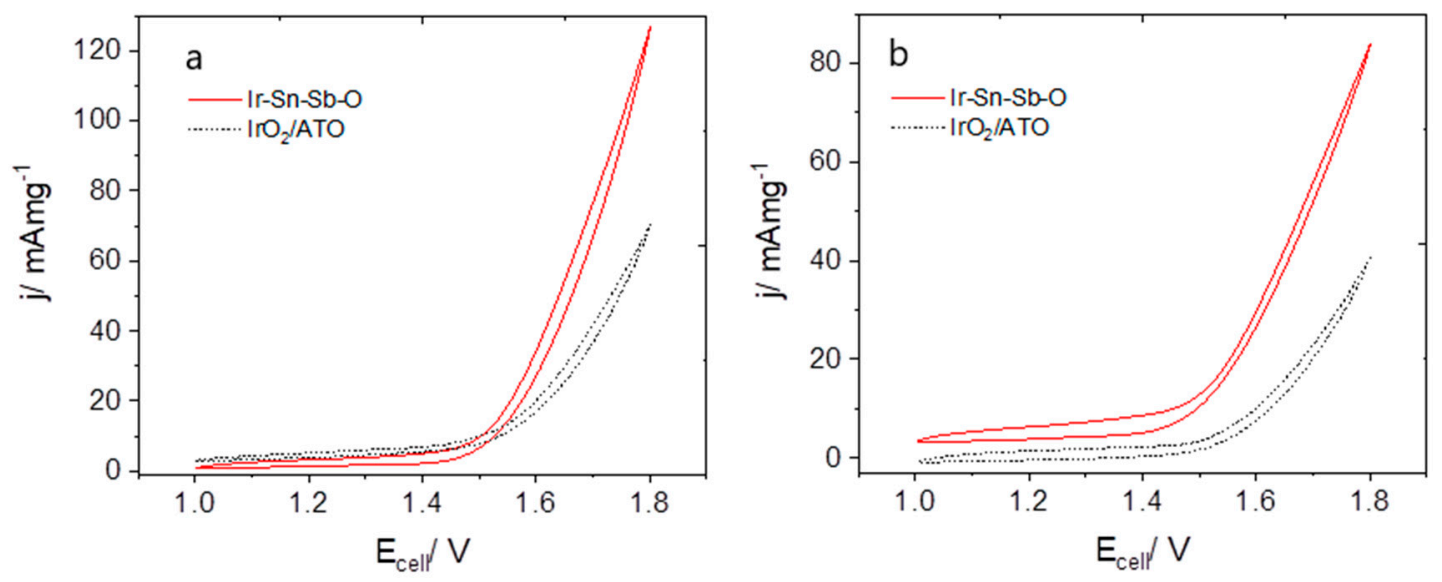

Figure 7. Cyclic voltammetry of $\mathrm{IrO}_{2} / \mathrm{ATO}(---)$ and $\mathrm{Ir}-\mathrm{Sn}-\mathrm{Sb}-\mathrm{O}$ (-) MEAs. (a) Before and (b) after polarization. $70{ }^{\circ} \mathrm{C}$ and $7 \mathrm{~mL} \mathrm{~min}^{-1}, v=100 \mathrm{mV} \mathrm{s}^{-1}$.

2.2.2. Electrochemical Impedance Spectroscopy

Figure 8 shows the EIS plots for the electrolysis cell assembled with $\mathrm{IrO}_{2} / \mathrm{ATO}$ and $\mathrm{Ir}-\mathrm{Sn}-\mathrm{Sb}-\mathrm{O}$ MEAs at 1.6 V. Figure 8a,b shows Nyquist and Bode plots respectively. At the high frequency region, impedances points can be observed with positive components in the imaginary impedance axis, 
which are related to inductive effects associated to the magnetic field created by the electrical current flow through the wiring and measuring components of the cell [48]. In Figure 8a, the intercept on the $Z_{\text {real }}$ axis corresponds to the cell ohmic resistance, which includes the resistance of wiring components, membrane and the resistance of the catalytic layer $[48,49]$. This value was used for ohmic drop correction of the polarization curves described below. It can be appreciated that ohmic resistance in both assemblies is similar. In addition, in both spectra, a depressed arc can be observed that includes two overlapped semicircles related to the interfacial impedance of the two electrodes. The presence of two electrode processes is revealed in a clearer form in the phase angle curve of Bode plots (Figure 8b), where the separate characteristic frequencies can be appreciated of two parallel R-C circuits. The projection of the arcs on the real impedance axis corresponds to the global charge transfer resistance associated with electrode reactions. It is easy to observe that the transfer resistance is smaller for the Ir-Sn-Sb-O catalyst than that for the mechanical mixture. In the insert of Figure 8a, the proposed equivalent circuit (EC) for the electrolysis system is shown. This circuit is similar to that previously reported [50]. In the EC, $\mathrm{L}$ is the inductor, $\mathrm{R}_{\mathrm{HF}}$ represents the resistance at high frequencies, $\mathrm{Rc}$ and $\mathrm{CPEc}$ correspond to a parallel arrangement between a resistor and a constant phase element associated with the processes in the cathode, and Ra and CPEa represent a second parallel circuit corresponding to the anodic process. The complex nonlinear least squares fitting (CNLS) of the experimental data obtained using the equivalent circuit discussed before is shown as continuous lines in Figure $8 \mathrm{a}, \mathrm{b}$. It can be observed that a good fit between the simulated and experimental data was obtained for both Nyquist and Bode graphics $\left(\chi^{2}=7.3 \times 10^{-6}\right)$. A summary of the EC element values obtained from the fitting are presented in Table 3.
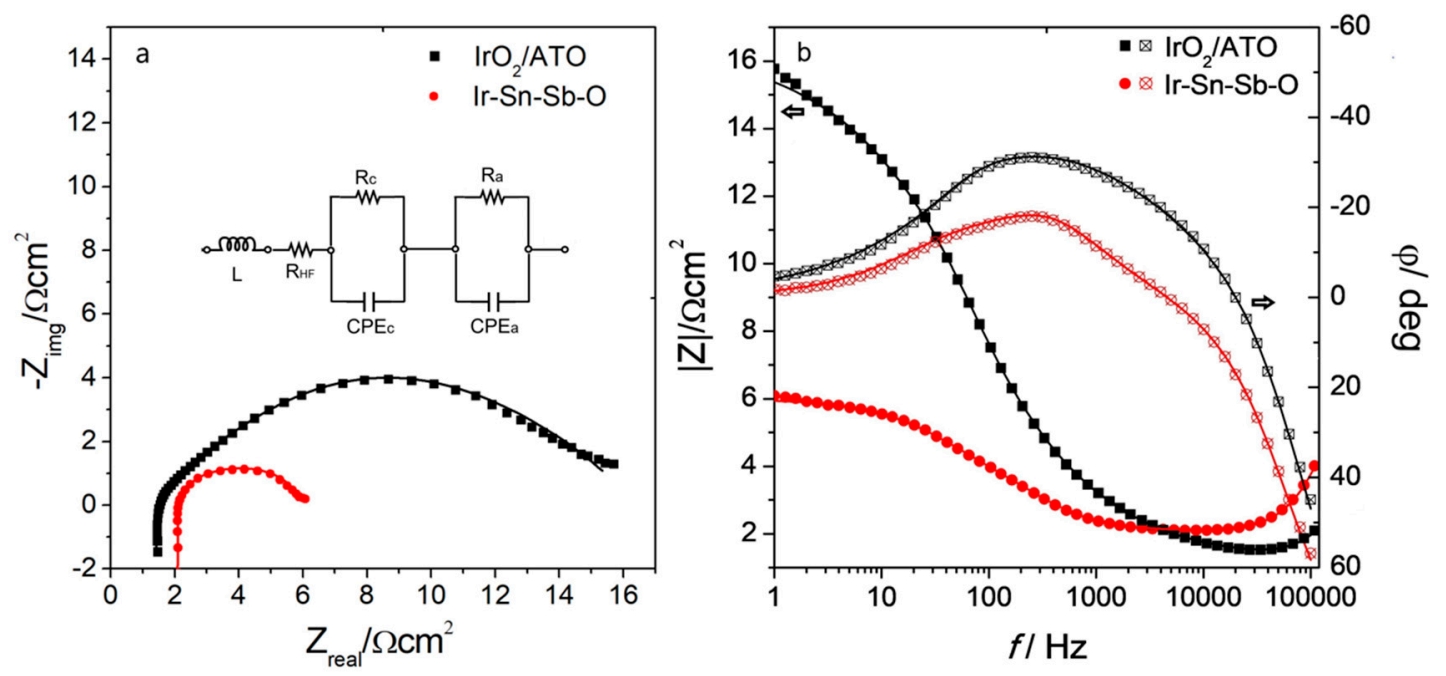

Figure 8. Electrochemical impedance spectroscopy (EIS) curves of $\mathrm{IrO}_{2} / \mathrm{ATO}(\boldsymbol{\bullet})$ and Ir-Sn-Sb-O (•), (a) Nyquist plot, insert: proposed equivalent circuit. (b) Bode plots. The continuous lines depict the complex nonlinear least squares (CNLS) simulation curves from the equivalent circuit. The spectra were obtained at $1.6 \mathrm{~V}, 70{ }^{\circ} \mathrm{C}$ and a water flux of $7 \mathrm{~mL} \mathrm{~min}^{-1}$.

Table 3. Equivalent circuit parameters obtained from CNLS fitting.

\begin{tabular}{|c|c|c|c|c|c|c|}
\hline Catalyst & $\mathbf{L} / \mathbf{H}$ & $\mathrm{R}_{\mathrm{HF}} / \Omega \mathrm{cm}^{2}$ & $\mathrm{R}_{\mathrm{c}} / \Omega \mathrm{cm}^{2}$ & $\mathrm{CPE}_{\mathrm{c}} / \mathrm{F} \mathrm{cm}^{-2}$ & $R_{a} / \Omega \mathrm{cm}^{2}$ & $\mathrm{CPE}_{\mathrm{a}} / \mathrm{F} \mathrm{cm}^{-2}$ \\
\hline $\mathrm{IrO}_{2} / \mathrm{ATO}$ & $6.26 \times 10^{-7}$ & 1.38 & 0.38 & 0.0018 & 14.16 & 0.0072 \\
\hline Ir-Sn-Sb-O & $1.03 \times 10^{-6}$ & 1.91 & 0.13 & 0.0038 & 3.95 & 0.0120 \\
\hline
\end{tabular}

From Table 3, we can appreciate that the inductance values due to the external circuitry were in the order of $10^{-6} \mathrm{H}$. This is in agreement with inductance values reported before and are related to framework cell components [51]. Furthermore, it is confirmed that the high frequency resistances values, close to $2 \Omega \mathrm{cm}^{2}$, were similar in both assemblies because the same electrolysis cell was used 
in all EIS experiments. The Ra value in both assemblies was higher than the Rc values; this result supports the fact that OER is the limiting reaction in water electrolysis. On the other hand, the anode charge transfer resistance of the Ir-Sn-Sb-O catalyst was 3.6 times smaller than that for the $\mathrm{IrO}_{2} / \mathrm{ATO}$ mixture, which means that the Ir-Sn-Sb-O material improves the global kinetics in the electrolyser, mainly the OER rate.

Figure $9 \mathrm{a}, \mathrm{b}$ show the Nyquist plots as a function of potential for $\mathrm{IrO}_{2} / \mathrm{ATO}$ and $\mathrm{Ir}-\mathrm{Sn}-\mathrm{Sb}-\mathrm{O}$ assemblies respectively. It can be clearly observed that the total impedance of both systems decreases as the applied voltage increases. The insets in Figure 9 present more detailed impedance curves for high potentials. For each applied potential the arc amplitudes were smaller for the Ir-Sn-Sb-O than for $\mathrm{IrO}_{2}$ /ATO. These results further confirm that the one pot synthesized material presented higher electroactivity for OER than the mechanical mixture catalyst for applications as anode.
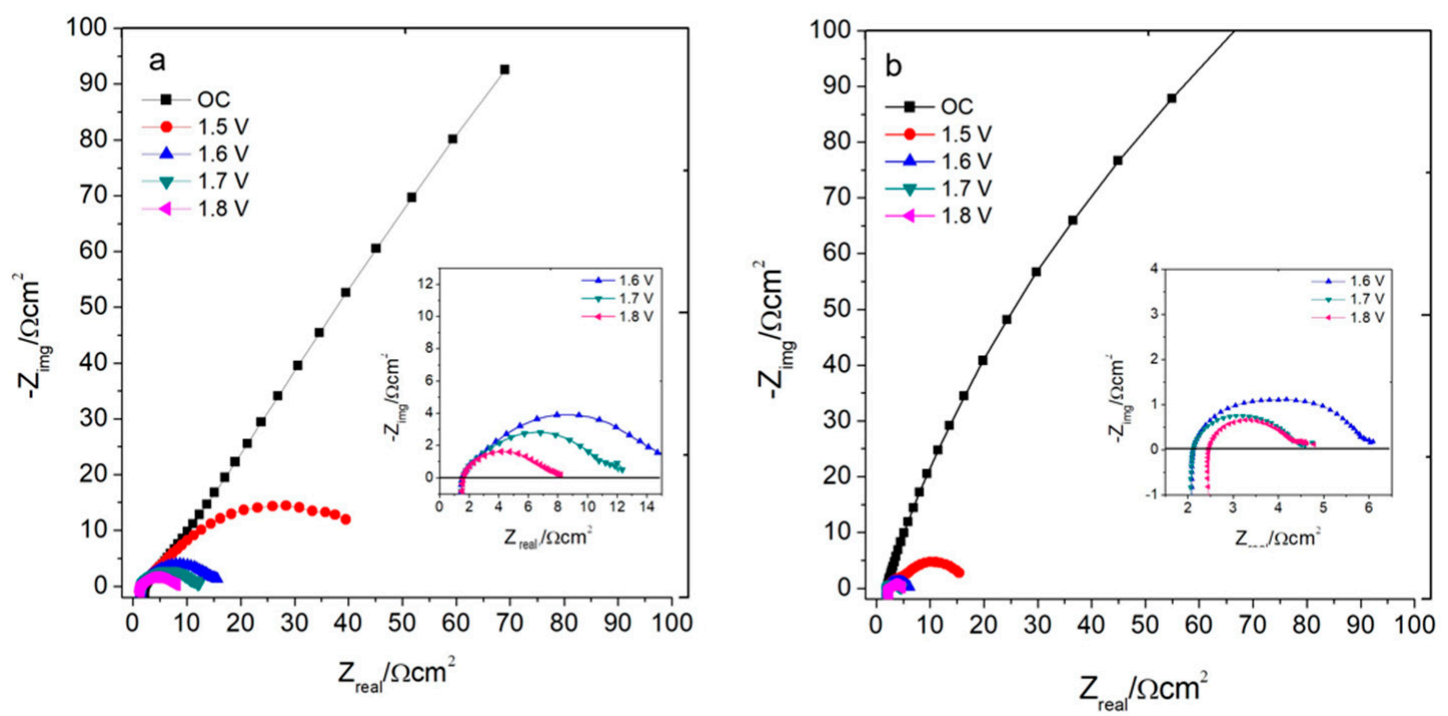

Figure 9. Electrochemical impedances spectra of (a) IrO2/ATO and (b) Ir-Sn-Sb-O.

\subsubsection{Electrolyser Performance}

Polarization curves, after ohmic drop correction, for a single cell electrolyser using $\mathrm{IrO}_{2} / \mathrm{ATO}$ or Ir-Sn-Sb-O as catalyst are shown in Figure 10. Although the electrolysis starts at around $1.45 \mathrm{~V}$ in both assemblies, a fast increase in current density when potential increases can be observed when mixed oxide is used in the anode, while a slower electrolysis curve was obtained for $\mathrm{IrO}_{2} / \mathrm{ATO}$. As a consequence, at $1.75 \mathrm{~V}$ the Ir-Sn-Sb-O assembled electrolyser reaches a current value of $254 \mathrm{~mA} \mathrm{mg}^{-1}$ against only $13.7 \mathrm{~mA} \mathrm{mg}^{-1}$ obtained when the supported $\mathrm{IrO}_{2}$ catalyst was used. These current density values are equivalent to oxygen volumetric flows of $5.77 \mathrm{~mL} \mathrm{~min}^{-1}$ and $0.78 \mathrm{~mL} \mathrm{~min}^{-1}$ respectively as estimated from Faraday's Law [52]. Assuming a quasi-linear behavior, the slope of the polarization curves also implies that the required overpotential to increase the current density by one order of magnitude (from 20 to $200 \mathrm{~mA} \mathrm{mg}^{-1}$ ) is 3.3 times higher for the $\mathrm{IrO}_{2} / \mathrm{ATO}$ mixture than for Ir-Sn-Sb-O when used as anode catalysts in a single cell. The internal resistance calculated from the slopes of the curves $\mathrm{E} / \mathrm{j}$ shown in Figure 10 correspond to $5.2 \Omega \mathrm{cm}^{2}$ and $2.4 \Omega \mathrm{cm}^{2}$ for $\mathrm{IrO}_{2} / \mathrm{ATO}$ and Ir-Sn-Sb-O respectively; these values are consistent with the global charge transfer resistance that can be obtained from EIS spectra at 1.7 V (inserts in Figure 9). 


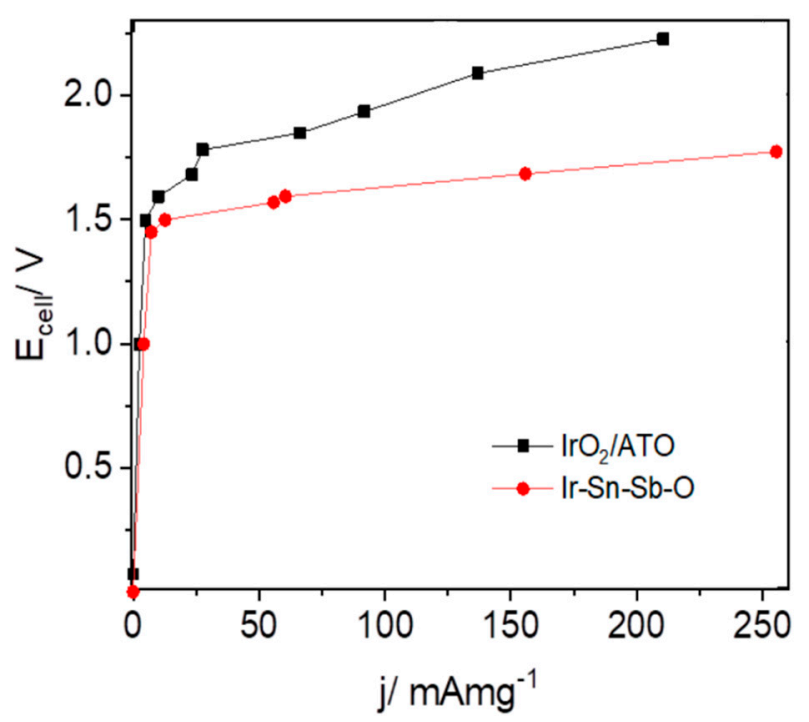

Figure 10. Polarization curves of $\operatorname{IrO}_{2} / \mathrm{ATO}(\boldsymbol{\square})$ and $\mathrm{Ir}-\mathrm{Sn}-\mathrm{Sb}-\mathrm{O}(\bullet)$ at $70{ }^{\circ} \mathrm{C}$ and $7 \mathrm{~mL} \mathrm{~min}{ }^{-1}$ of water.

Additionally, the onset potential for Ir-Sn-Sb-O is similar to some values reported in the literature, even though the experimental conditions used are not equivalent. Marshall et al. [7] have reported an $\mathrm{E}_{\mathrm{OER}}$ close to $1.45 \mathrm{~V}$, with current density close to $1 \mathrm{~mA} \mathrm{~cm}{ }^{-2}$ at $1.5 \mathrm{~V}$ for $\operatorname{Ir}_{0.5} \mathrm{Sn}_{0.5} \mathrm{O}_{2}$ mixtures. Siracusano et al. [8], reported a similar onset potential for OER in acidic media, close to $1.45 \mathrm{~V}$, in a single cell for unsupported catalyst $\operatorname{Ir}_{0.7} \mathrm{Ru}_{0.3} \mathrm{O}_{x}$. On the other hand, a current density value of $254 \mathrm{~mA} \mathrm{mg}^{-1}$ was registered at $1.75 \mathrm{~V}$ for Ir-Sn-Sb-O as catalyst anode in the single cell electrolyser. Here, it is important to mention that a low catalyst load was used $\left(0.5 \mathrm{mg} \mathrm{cm}^{-2}\right)$ in the anode. Thus, a small current density was obtained in this study as compared with those values, $>1 \mathrm{~A} \mathrm{~cm}^{-2}$, reported in the literature for most $\mathrm{IrO}_{2}$-based catalysts and at higher catalyst loads, in current PEM water electrolysis systems $[7,53]$.

Therefore, the single cell electrolyser results shown here suggest that Ir-Sn-Sb-O can be considered as a potential anodic electrocatalyst in water electrolysis.

\subsubsection{Chronoamperometry}

A first evidence of the stability test for Ir-Sn-Sb-O was performed by applying a constant potential of $1.8 \mathrm{~V}$ during $10 \mathrm{~h}$. The chronoamperometric results are shown in Figure 11. After the initial abrupt increase in current density, a rapid drop is observed until a relative stabilization is reached at about $40 \mathrm{~min}$ and at a current density value of $70 \mathrm{~mA} \mathrm{mg}^{-1}$. The current value remains practically constant through the testing period, reaching a final value of $64 \mathrm{~mA} \mathrm{mg}^{-1}$ in $600 \mathrm{~min}$. A current drop of only $10 \%$ of the initial steady state value was obtained at the end of the experiment. This is evidence that the catalyst presents good stability under the experimental conditions employed.

Several authors have performed a similar stability evaluation using chronopotentiometry as reported in this work but longer periods greater than $100 \mathrm{~h}$ have been used. For instance, Yu et al. [54] reported an increase in the potential from $1.97 \mathrm{~V}$ to $2.10 \mathrm{~V}$ in a period of $250 \mathrm{~h}$, when a current density of $1.8 \mathrm{~A} \mathrm{~cm}^{-2}$ was imposed on a PEM electrolyser with a MEA area of $28 \mathrm{~cm}^{2}$ and a Ir-based catalyst with a catalytic loading of $0.04 \mathrm{mg} \mathrm{cm}^{-2}$ was used as anode. Siracusano et al. [55] reported chronopotentiometry as a durability test for $1000 \mathrm{~h}$ at $3 \mathrm{~A} \mathrm{~cm}^{-2}$ for a IrRuO $\mathrm{I}_{\mathrm{x}}$ catalyst in a single cell electrolyser. A significant increase in the cell overpotential at the applied current was not observed. Although the chronoamperometric results obtained for Ir-Sn-Sb-O may be considered as first evidence of the stability of the electrocatalyst in acidic media, corroboration of the stability properties under higher current densities and for longer periods is deserved. 


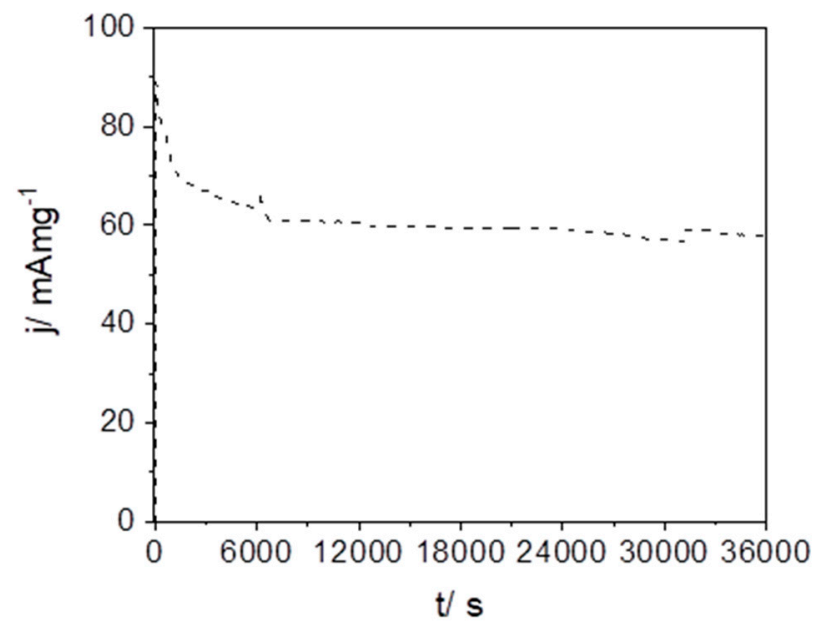

Figure 11. Stability study of Ir-Sn-Sb-O catalyst in single cell at $1.8 \mathrm{~V}$ and $60^{\circ} \mathrm{C}$ for a period of $10 \mathrm{~h}$.

\section{Materials and Methods}

\subsection{Mixed Oxide Synthesis}

The catalysts for the oxygen evolution reaction were prepared using conventional thermal decomposition with the precursors $\mathrm{H}_{2} \mathrm{IrCl}_{6}, \mathrm{SnCl}_{4} \cdot 5 \mathrm{H}_{2} \mathrm{O}$ and $\mathrm{SbCl}_{3}$ (Aldrich, St. Louis, MO, USA). The metal precursor proportions used for the synthesis corresponded to (1) 40 at.\% Ir, 57 at.\% Sn and 3 at.\% Sb for Ir-Sn-Sb-O synthesis, (2) 100 at.\% Ir for $\mathrm{IrO}_{2}$ synthesis and (3) 95 at.\% $\mathrm{Sn}$ and 5 at.\% $\mathrm{Sb}$ for ATO. The synthesis procedure used has been previously reported [39]. In brief, $50 \mathrm{~mL}$ of a $0.25 \mathrm{M}$ ethanolic solution was prepared considering the atomic percentages of the precursor salts previously mentioned. The solution was placed in a flask, heated at $50{ }^{\circ} \mathrm{C}$ (using a mineral oil bath) and stirred under a $\mathrm{N}_{2}$ atmosphere for $2 \mathrm{~h}$. The ethanol was evaporated at $80^{\circ} \mathrm{C}$ for $2 \mathrm{~h}$ in a drying oven. The precursor was then calcined at $450{ }^{\circ} \mathrm{C}$ for $0.5 \mathrm{~h}$ under air flux in a tube furnace 21,100 Barnstead (Thermo Fisher Scientific, Waltham, MA, USA) to obtain the final oxide. A quartz tube was used as container. The obtained catalyst material was washed three times with hot water and later once with methanol. Finally, the obtained powder was oven dried at $80^{\circ} \mathrm{C}$.

\subsection{Physicochemical Characterization}

The electrical resistivity, $\rho$, four points measurements were performed using an 4338B miliohmeter (Agilent, St. Clara CA, USA) at room temperature. In order to control the pressure of powder compacting, a stainless steel home-made cylinder-piston system was used. The resistivity measurements were obtained by compressing the powders using a 4386 mechanical press (Carver Inc., Wabash, IN, USA) at pressures from 0 to 200 psi. The electrical conductivity $(\sigma)$ was calculated from the equation $\sigma=1 / \rho=L /(R A)$, where L/A corresponds to the geometrical correction factor of the measurement system.

Scanning electron microscopy images were acquired using an JSEM 7401F microscope (JEOL, Tokyo, Japan), with a field emission gun at an accelerating voltage of $30 \mathrm{kV}$. Transmission electron microscopy was performed with a JEM-2200FS instrument (JEOL, Tokyo, Japan) with a field emission gun at an accelerating voltage of $200 \mathrm{kV}$, and the microscopic atomic composition of the materials was measured using an energy dispersive analyzer coupled with TEM.

X-ray diffraction analysis was performed using an Xpert PRO diffractometer (Malvert Panalytical, Almedo, The Netherlands) with an $X^{\prime}$ Celerator detector and $\mathrm{Cu} \mathrm{K} \alpha$ radiation. Temperature programmed reduction was conducted using a ChemiSorb 2720 instrument (Micromeritics, Norcross, GA, USA) through the ChemiSoft TPx software. A temperature scan from $25^{\circ} \mathrm{C}$ to $850{ }^{\circ} \mathrm{C}$ was employed with a heating rate of $10{ }^{\circ} \mathrm{C} \mathrm{min}^{-1}$ under a flux of $30 \mathrm{~mL} \mathrm{~min}^{-1}$ of $10 \% \mathrm{H}_{2} / \mathrm{Ar}$ gas mixture. Prior to the analysis, the samples were dried for $20 \mathrm{~min}$ at $150{ }^{\circ} \mathrm{C}$ under $\mathrm{N}_{2}$ flux. 


\subsection{Membrane Electrode Assembly}

Membrane electrode assemblies (MEAs) were prepared through a method previously reported [36,38,56]. A Nafion 117 membrane (Aldrich, St. Louis, MO, USA) was used as solid polymer electrolyte. Catalytic inks were prepared and deposited over the Nafion membrane using a sprayer. Later, the MEA was hot pressed using a 4386 mechanical press (Carver Inc., Wabash, IN, USA) at $200 \mathrm{psi}$ and $80^{\circ} \mathrm{C}$ for $30 \mathrm{~s}$. For the cathode, the catalytic ink consisted of a mixture of ethanol, Nafion ${ }^{\circledR}$ perfluorinated resin solution, $5 \mathrm{wt}$. \% in lower aliphatic alcohols and water (Aldrich) and $5 \mathrm{wt} . \% \mathrm{Pt} / \mathrm{C}$ catalyst (Premetek, Cherry Hill, NJ, USA) to obtain a final platinum load of $0.2 \mathrm{mg}$ $\mathrm{cm}^{-2}$. At the anode, the ink was composed of synthesized Ir-Sn-Sb-O or a mechanical mixture of $\mathrm{IrO}_{2} / \mathrm{ATO}$ (40 at.\% of $\mathrm{IrO}_{2}$ ) and $10 \mathrm{wt} . \%$ of Nafion solution dispersed in ethanol. For both catalysts, the final load was $2.6 \mathrm{mg} \mathrm{cm}^{-2}$, equivalent to $0.5 \mathrm{mg} \mathrm{cm}^{-2}$ of Ir metal. The electrodes were previously activated at $2 \mathrm{~V}$ and $80^{\circ} \mathrm{C}$ for $2 \mathrm{~h}$.

\subsection{Single Cell Electrochemistry}

The electrocatalytic activities of Ir-Sn-Sb-O and the mechanical mixture of $\mathrm{IrO}_{2} / \mathrm{ATO}$ were evaluated in single cell PEMWE with an MEA active area of $4 \mathrm{~cm}^{2}$. The cell included two monopolar plates made of titanium with a parallel flow configuration. Two sintered titanium plates of $70 \%$ average porosity were employed as diffusors and two stainless steel plates were used as end plates. All single cell tests were performed using a flow rate of water of $7 \mathrm{~mL} \mathrm{~min}^{-1}$ at $70{ }^{\circ} \mathrm{C}$ using a peristaltic pump (WPI, Sarasota, FL, USA).

The electrochemical properties of the catalysts were evaluated using cyclic voltammetry (CV) and electrochemical impedance spectroscopy (EIS) in the single cell. Ir-Sn-Sb-O or $\mathrm{IrO}_{2} / \mathrm{ATO}$ catalyst was used as anode and $\mathrm{Pt} / \mathrm{C}$ catalyst as cathode. The electrodes were prepared as described above. At the cathode a carbon mesh was employed as gas diffusor. A potential scan rate of $100 \mathrm{mV} \mathrm{s}^{-1}$ was used for all $\mathrm{CV}$ tests in a potential window from 1 to $1.8 \mathrm{~V}$ before and after polarization curves. The EIS measurements were conducted in a frequency region from $10^{5}$ to $1 \mathrm{~Hz}$, in a potential range between 1.5 to $1.8 \mathrm{~V}$ for both assemblies. A sinusoidal potential perturbation of $5 \mathrm{mV}$ amplitude was employed. The polarization curves were obtained using chronopotentiometry $(\mathrm{CP})$ measurements and were conducted within a current density range from $0 \mathrm{~mA} \mathrm{mg}^{-1}$ to $300 \mathrm{~mA} \mathrm{mg}^{-1}$ for both catalysts. The time of the potential stabilization was $1 \mathrm{~min}$. Open circuit EIS was measured before and after polarization curves were collected. All electrochemical tests were performed using a Reference 600 potentiostat/galvanostat (Gamry, Warminster, PA, USA). The operation temperature in the electrolytic cell was maintained at $70^{\circ} \mathrm{C}$ using a MD-BASIS thermostatic bath (Julabo, Seelbach, Germany).

\section{Conclusions}

A mixed oxide material based on Ir, Sn and Sb with both electrocatalyst and support characteristics for OER was synthesized using the one pot method, by simple thermal decomposition of metallic salts. The physicochemical properties and electrochemical activity of the Ir-Sn-Sb-O material was compared with an equivalent $\mathrm{IrO}_{2}$ catalyst supported on ATO. The analyses of the Ir-Sn-Sb-O indicate that the obtained catalyst is a heterogeneous mixture of nano-particled oxides of $\mathrm{Ir}$, $\mathrm{Sn}$ and $\mathrm{Sb}$, with small particles $(\sim 6 \mathrm{~nm})$ of $\mathrm{IrO}_{2}$ and $\mathrm{IrO}_{\mathrm{x}}$ and bigger particles $(>50 \mathrm{~nm})$ of $\mathrm{Sb}$ doped $\mathrm{SnO}_{2}$. The analytical results also confirmed the presence of metallic Ir in the synthesized catalyst. The Ir-Sn-Sb-O presented a higher electrical conductivity than the $\mathrm{IrO}_{2} / \mathrm{ATO}$, meaning an improved electronic transport through the mixed oxide material. The results obtained from CV, EIS and single cell performance are consistent with a better electroactivity of Ir-Sn-Sb-O in respect to $\mathrm{IrO}_{2} / \mathrm{ATO}$ for oxygen evolution reaction. The stability of the Ir-Sn-Sb-O catalyst during OER as evaluated using chronoamperometry over a few hours indicates a non-significant electrolysis current drop, suggesting, in a first instance, that the mixed oxide is a stable material. 
The improved catalytic performance of the mixed oxide can be attributed to a possible synergistic effect between iridium dioxide, amorphous iridium oxide and ATO. It is possible that the presence of multiple iridium oxide species and their interaction with doped tin oxide favors the overlapping of inner d-orbitals of Ir, thus increasing the electron conduction of the mixed oxide [57]. However, the need for in-depth kinetics and catalysis studies in relation to the structure are suggested to elucidate the mechanism details of OER on this kind of material. It is also mandatory to optimize and perform benchmark electrolysis experiments in order to adequately compare the electrocatalytic properties of the obtained Ir-Sb-Sn-O material with those of "state of the art" on OER catalysts.

According to the properties of Ir-Sn-Sb-O reported in this work, it is suggested that this material synthesized in a single step is a promising anodic catalyst for SPEWE.

Author Contributions: Conceptualization, N.J.P.-V. and S.M.D.-T.; formal analysis, N.J.P.-V., V.H.C.-M. and S.M.D.-T.; funding acquisition, S.M.D.-T.; investigation, N.J.P.-V., I.L.E.-G., J.R.F.-H. and S.M.D.-T.; methodology, N.J.P.-V., V.H.C.-M., I.L.E.-G., J.R.F.-H., M.G.-V. and S.M.D.-T.; project administration, S.M.D.-T.; supervision, S.M.D.-T.; validation, N.J.P.-V.; writing—original draft, N.J.P.-V. and S.M.D.-T.; writing—review and editing, N.J.P.-V., M.G.-V. and S.M.D.-T. All authors have read and agreed to the published version of the manuscript.

Funding: This research received no external funding.

Acknowledgments: The authors are thankful to Eng. Miguel J. Meléndez, M. Sc. Carlos E. Ornelas M. Sc. Karla Campos, Eng. Wilber Antunez and M. Sc. Ernesto Guerrero for their contributions to the TEM, SEM and XRD results. Special acknowledgements are given to Laboratorio Nacional de Nanotecnología in Centro de Investigación en Materiales Avanzados S. C. for their support in the use of the facilities. Particular gratitude goes to Ana I. Peña of Laboratorio Nacional de Investigación en Nanociencias y Nanotecnología in Instituto Potosino de Investigación Científica y Tecnológica. N.J. Pérez thanks CONACyT for a graduate fellowship.

Conflicts of Interest: The authors declare no conflicts of interest.

\section{References}

1. Chaubey, R.; Sahu, S.; James, O.; Maity, S. A review on development of industrial processes and emerging techniques for production of hydrogen from renewable and sustainable sources. Renew. Sustain. Energy Rev. 2013, 23, 443-462. [CrossRef]

2. Azwar, M.Y.; Hussain, M.A.; Abdul-Wahab, A.K. Development of biohydrogen production by photobiological, fermentation and electrochemical processes: A review. Renew. Sustain. Energy Rev. 2014, 31, $158-173$. [CrossRef]

3. Stiller, C.; Hochrinner, H. Use of Conventional and Green Hydrogen in the Chemical Industry. In Hydrogen and Fuel Cell; Töpler, J., Lehmann, J., Eds.; Springer: Berlin/Heidelberg, Germany, 2016; pp. 173-186. ISBN 978-3-662-44971-4.

4. Alves, V.A.; da Silva, L.A.; Boodts, J.F.C.; Trasatti, S. Kinetics and mechanism of oxygen evolution on $\mathrm{IrO}_{2}$-based electrodes containing Ti and Ce acidic solutions. Electrochim. Acta 1994, 39, 1585-1589. [CrossRef]

5. Abreu-Sepulveda, M.; Trinh, P.; Malkhandi, S.; Narayanan, S.R.; Jorné, J.; Quesnel, D.J.; Postonr, J.A., Jr.; Manivannan, A. Investigation of Oxygen Evolution Reaction at LaRuO3, La3.5Ru4O13, and La2RuO5. Electrochim. Acta 2015, 180, 401-408. [CrossRef]

6. Giordano, L.; Han, B.; Risch, M.; Hong, W.T.; Rao, R.R.; Stoerzinger, K.A.; Shao-Horn, Y. pH dependence of OER activity of oxides: Current and future perspectives. Catal. Today 2016, 262, 2-10. [CrossRef]

7. Carmo, M.; Fritz, D.L.; Mergel, J.; Stolten, D. A comprehensive review on PEM water electrolysis. Int. J. Hydrogen Energy 2013, 38, 4901-4934. [CrossRef]

8. Millet, P.; Ngameni, R.; Grigoriev, S.A.; Mbemba, N.; Brisset, F.; Ranjbari, A.; Etiévant, C. PEM water electrolyzers: From electrocatalysis to stack development. Int. J. Hydrogen Energy 2010, 35, 5043-5052. [CrossRef]

9. Agbli, K.S.; Péra, M.C.; Hissel, D.; Rallières, O.; Turpin, C.; Doumbia, I. Multiphysics simulation of a PEM electrolyser: Energetic Macroscopic Representation approach. Int. J. Hydrogen Energy 2011, 36, 1382-1398. [CrossRef]

10. Chandesris, M.; Médeau, V.; Guillet, N.; Chelghoum, S.; Thoby, D.; Fouda-Onana, F. Membrane degradation in PEM water electrolyzer: Numerical modeling and experimental evidence of the influence of temperature and current density. Int. J. Hydrogen Energy 2015, 40, 1353-1366. [CrossRef] 
11. Lee, J.; Jeong, B.; Ocon, J.D. Oxygen electrocatalysis in chemical energy conversion and storage technologies. Curr. Appl. Phys. 2013, 13, 309-321. [CrossRef]

12. Lasia, A. Mechanism and kinetics of the hydrogen evolution reaction. Int. J. Hydrogen Energy 2019, 44, 19484-19518. [CrossRef]

13. Reier, T.; Oezaslan, M.; Strasser, P. Electrocatalytic Oxygen Evolution Reaction (OER) on Ru, Ir, and Pt Catalysts: A Comparative Study of Nanoparticles and Bulk Materials. ACS Catal. 2012, 2, 1765-1772. [CrossRef]

14. Jamesh, M.-I.; Sun, X. Recent progress on earth abundant electrocatalysts for oxygen evolution reaction (OER) in alkaline medium to achieve efficient water splitting-A review. J. Power Sources 2018, 400, 31-68. [CrossRef]

15. Ahmed, J.; Mao, Y. Ultrafine Iridium Oxide Nanorods Synthesized by Molten Salt Method toward Electrocatalytic Oxygen and Hydrogen Evolution Reactions. Electrochim. Acta 2016, 212, 686-693. [CrossRef]

16. Rubel, M.; Haasch, R.; Mrozek, P.; Wieckowski, A.; De Pauli, C.; Trasatti, S. Characterization of IrO2-SnO2 thin layers by electron and ion spectroscopies. Vacuum 1994, 45, 423-427. [CrossRef]

17. Ardizzone, S.; Fregonara, G.; Trasatti, S. "Inner" and "outer" active surface of RuO2 electrodes. Electrochim. Acta 1990, 35, 263-267. [CrossRef]

18. Audichon, T.; Mayousse, E.; Morisset, S.; Morais, C.; Comminges, C.; Napporn, T.W.; Kokoh, K.B. Electroactivity of $\mathrm{RuO} 2-\mathrm{IrO} 2$ mixed nanocatalysts toward the oxygen evolution reaction in a water electrolyzer supplied by a solar profile. Int. J. Hydrogen Energy 2014, 39, 16785-16796. [CrossRef]

19. Cherevko, S.; Geiger, S.; Kasian, O.; Kulyk, N.; Grote, J.-P.; Savan, A.; Shrestha, B.R.; Merzlikin, S.; Breitbach, B.; Ludwig, A.; et al. Oxygen and hydrogen evolution reactions on $\mathrm{Ru}, \mathrm{RuO}_{2}$, $\mathrm{Ir}$, and $\mathrm{IrO}_{2}$ thin film electrodes in acidic and alkaline electrolytes: A comparative study on activity and stability. Catal. Today 2016, 262, 170-180. [CrossRef]

20. Alonso-Vante, N. Photocatalysis an enhancer of electrocatalytic process. Curr. Opin. Electrochem. 2018, 9, 114-120. [CrossRef]

21. Ávila-Vázquez, V.; Cruz, J.C.; Galván-Valencia, M.; Ledesma-García, J.; Arriaga, L.G.; Guzmán, C.; Durón-Torres, S.M. Electrochemical study of Sb-doped $\mathrm{SnO}_{2}$ supports on the oxygen evolution reaction: Effect of synthesis annealing time. Int. J. Electrochem. Sci. 2013, 8, 10586-10600.

22. Dimitrov, M.; Guncheva, M.; Zhiryakova, D.; Lazarova, T.; Lalev, G.; Tsoncheva, T. Nanostructured tin dioxide-A promising multipurpose support material for catalytic and biocatalytic applications. Chem. Eng. J. 2014, 252, 55-63. [CrossRef]

23. Du, C.; Chen, M.; Cao, X.; Yin, G.; Shi, P. A novel CNT-SnO 2 core-sheath nanocomposite as a stabilizing support for catalysts of proton exchange membrane fuel cells. Electrochem. Commun. 2009, 11, 496-498. [CrossRef]

24. Jia, Y.; Jiang, K.; Wang, H.; Yao, X. The Role of Defect Sites in Nanomaterials for Electrocatalytic Energy Conversion. Chem 2019, 5, 1371-1397. [CrossRef]

25. Keeler, A.J.; Salazar-Banda, G.R.; Russell, A.E. Mechanistic insights into electrocatalytic reactions provided by SERS. Curr. Opin. Electrochem. 2019, 17, 90-96. [CrossRef]

26. Hagemeyer, A.; Hogan, Z.; Schlichter, M.; Smaka, B.; Streukens, G.; Turner, H.; Volpe, A.; Weinberg, H.; Yaccato, K. High surface area tin oxide. Appl. Catal. A Gen. 2007, 317, 139-148. [CrossRef]

27. Murakami, Y.; Ohkawauchi, H.; Ito, M.; Yahikozawa, K.; Takasu, Y. Preparations of ultrafine $\mathrm{IrO}_{2}-\mathrm{SnO}_{2}$ binary oxide particles by a sol-gel process. Electrochim. Acta 1994, 39, 2551-2554. [CrossRef]

28. Kadakia, K.; Datta, M.K.; Velikokhatnyi, O.I.; Jampani, P.H.; Kumta, P.N. Fluorine doped (Ir,Sn,Nb)O 2 anode electro-catalyst for oxygen evolution via PEM based water electrolysis. Int. J. Hydrogen Energy 2014, 39, 664-674. [CrossRef]

29. Baker, P.G.L.; Sanderson, R.D.; Crouch, A.M. Sol-gel preparation and characterisation of mixed metal tin oxide thin films. Thin Solid Films 2007, 515, 6691-6697. [CrossRef]

30. Balko, E.N.; Nguyen, P.H. Iridium-tin mixed oxide anode coatings. J. Appl. Electrochem. 1991, 21, 678-682. [CrossRef]

31. Biesinger, M.C.; Payne, B.P.; Lau, L.W.M.; Gerson, A.; Smart, R.S.C. X-ray photoelectron spectroscopic chemical state quantification of mixed nickel metal, oxide and hydroxide systems. Surf. Interface Anal. 2009, 41, 324-332. [CrossRef] 
32. Browne, M.P.; Nolan, H.; Duesberg, G.S.; Colavita, P.E.; Lyons, M.E.G. Low-Overpotential High-Activity Mixed Manganese and Ruthenium Oxide Electrocatalysts for Oxygen Evolution Reaction in Alkaline Media. ACS Catal. 2016, 6, 2408-2415. [CrossRef]

33. De Pauli, C.P.; Trasatti, S. Electrochemical surface characterization of $\mathrm{IrO}_{2}+\mathrm{SnO}_{2}$ mixed oxide electrocatalysts. J. Electroanal. Chem. 1995, 396, 161-168. [CrossRef]

34. Pintar, A.; Batista, J.; Hočevar, S. Redox Behavior of $(\mathrm{CuO})_{0.15}(\mathrm{CeO} 2)_{0.85}$ Mixed Oxide Catalyst Prepared by Sol-Gel Peroxide Method. Acta Chim. Slov. 2005, 52, 44-52.

35. Tan, F.K.; Hassan, J.; Wahab, Z.A.; Azis, R.S. Electrical conductivity and dielectric behaviour of manganese and vanadium mixed oxide prepared by conventional solid state method. Eng. Sci. Technol. 2016, 19, 2081-2087. [CrossRef]

36. Marshall, A.; Tsypkin, M.; Boørresen, B.; Hagen, G.; Tunold, R. Nanocrystalline $\mathrm{Ir}_{\mathrm{x}} \mathrm{Sn}_{(1-\mathrm{X})} \mathrm{O}_{2}$ electrocatalysts for oxygen evolution in water electrolysis with polymer electrolyte-Effect of heat treatment. J. New Mater. Electrochem. Syst. 2004, 7, 197-204.

37. Marshall, A.; Børresen, B.; Hagen, G.; Tsypkin, M.; Tunold, R. Electrochemical characterisation of $\operatorname{IrxSn}_{1-x} \mathrm{O}_{2}$ powders as oxygen evolution electrocatalysts. Electrochim. Acta 2006, 51, 3161-3167. [CrossRef]

38. Marshall, A.; Børresen, B.; Hagen, G.; Tsypkin, M.; Tunold, R. Hydrogen production by advanced proton exchange membrane (PEM) water electrolysers-Reduced energy consumption by improved electrocatalysis. Energy 2007, 32, 431-436. [CrossRef]

39. Pérez-Viramontes, N.J.; Escalante-García, I.L.; Guzmán-Martínez, C.; Galván-Valencia, M.; Durón-Torres, S.M. Electrochemical study of Ir-Sn-Sb-O materials as catalyst-supports for the oxygen evolution reaction. J. Appl. Electrochem. 2015, 45, 1165-1173. [CrossRef]

40. Oh, H.-S.; Nong, H.N.; Strasser, P. Preparation of Mesoporous Sb-, F-, and In-Doped SnO2 Bulk Powder with High Surface Area for Use as Catalyst Supports in Electrolytic Cells. Adv. Funct. Mater. 2015, 25, 1074-1081. [CrossRef]

41. Marshall, A.; Borresen, B.; Hagen, G.; Tsypkin, M.; Tunold, R. Preparation and characterisation of nanocrystalline IrSnO electrocatalytic powders. Mater. Chem. Phys. 2005, 94, 226-232. [CrossRef]

42. Ávila-Vázquez, V.; Galván-Valencia, M.; Ledesma-García, J.; Arriaga, L.G.; Collins-Martínez, V.H.; Guzmán-Martínez, C.; Escalante-Garcia, I.L.; Durón-Torres, S.M. Electrochemical performance of a Sb-doped $\mathrm{SnO} 2$ support synthesized by coprecipitation for oxygen reactions. J. Appl. Electrochem. 2015, 45, 1175-1185. [CrossRef]

43. Puthiyapura, V.K.; Pasupathi, S.; Su, H.; Liu, X.; Pollet, B.; Scott, K. Investigation of supported IrO2 as electrocatalyst for the oxygen evolution reaction in proton exchange membrane water electrolyser. Int. J. Hydrogen Energy 2014, 39, 1905-1913. [CrossRef]

44. Pfeifer, V.; Jones, T.E.; Velasco Vélez, J.J.; Massué, C.; Greiner, M.T.; Arrigo, R.; Teschner, D.; Girgsdies, F.; Scherzer, M.; Allan, J.; et al. The electronic structure of iridium oxide electrodes active in water splitting. Phys. Chem. Chem. Phys. 2016, 18, 2292-2296. [CrossRef] [PubMed]

45. Hughes, V.B.; McNicol, B.D. Evaluation of semiconducting tin oxide as an electrocatalyst support. J. Chem. Soc. Faraday Trans. 1 Phys. Chem. Condens. Phases 1979, 75, 2165. [CrossRef]

46. Xiang, C.; Papadantonakis, K.M.; Lewis, N.S. Principles and implementations of electrolysis systems for water splitting. Mater. Horiz. 2016, 3, 169-173. [CrossRef]

47. Bessarabov, D.; Millet, P. PEM Water Electrolysis; Academic Press: London, UK, 2018; Volume 1, ISBN 9780128111468.

48. Lasia, A. Electrochemical Impedance Spectroscopy and Its Applications; Springer-Verlag: New York, NY, USA, 2014; ISBN 978-1-4614-8932-0.

49. Sunde, S.; Lervik, I.A.; Owe, L.-E.; Tsypkin, M. An impedance model for a porous intercalation electrode with mixed conductivity. J. Electrochem. Soc. 2009, 156, B927-B937. [CrossRef]

50. Lettenmeier, P.; Kolb, S.; Sata, N.; Fallisch, A.; Zielke, L.; Thiele, S.; Gago, A.S.; Friedrich, K.A. Comprehensive investigation of novel pore-graded gas diffusion layers for high-performance and cost-effective proton exchange membrane electrolyzers. Energy Environ. Sci. 2017, 10, 2521-2533. [CrossRef]

51. Hu, J.-M.; Zhang, J.-Q.; Cao, C.-N. Oxygen evolution reaction on IrO2-based DSA®type electrodes: Kinetics analysis of Tafel lines and EIS. Int. J. Hydrogen Energy 2004, 29, 791-797. [CrossRef]

52. Yigit, T.; Selamet, O.F. Mathematical modeling and dynamic Simulink simulation of high-pressure PEM electrolyzer system. Int. J. Hydrogen Energy 2016, 41, 13901-13914. [CrossRef] 
53. Yu, H.; Danilovic, N.; Wang, Y.; Willis, W.; Poozhikunnath, A.; Bonville, L.; Capuano, C.; Ayers, K.; Maric, R. Nano-size IrOx catalyst of high activity and stability in PEM water electrolyzer with ultra-low iridium loading. Appl. Catal. B Environ. 2018, 239, 133-146. [CrossRef]

54. Buttler, A.; Spliethoff, H. Current status of water electrolysis for energy storage, grid balancing and sector coupling via power-to-gas and power-to-liquids: A review. Renew. Sustain. Energy Rev. 2018, 82, 2440-2454. [CrossRef]

55. Siracusano, S.; Baglio, V.; Van Dijk, N.; Merlo, L.; Aricò, A.S. Enhanced performance and durability of low catalyst loading PEM water electrolyser based on a short-side chain perfluorosulfonic ionomer. Appl. Energy 2017, 192, 477-489. [CrossRef]

56. Ardizzone, S.; Bianchi, C.L.; Cappelletti, G.; Ionita, M.; Minguzzi, A.; Rondinini, S.; Vertova, A. Composite ternary $\mathrm{SnO}_{2}-\mathrm{IrO}_{2}-\mathrm{Ta}_{2} \mathrm{O}_{5}$ oxide electrocatalysts. J. Electroanal. Chem. 2006, 589, 160-166. [CrossRef]

57. Trasatti, S.; Buzzanca, G. Ruthenium dioxide-New interesting electrode material-solid state structure and electrochemical behaviour. J. Electroanal. Chem. 1971, 29, A1. [CrossRef]

(C) 2020 by the authors. Licensee MDPI, Basel, Switzerland. This article is an open access article distributed under the terms and conditions of the Creative Commons Attribution (CC BY) license (http://creativecommons.org/licenses/by/4.0/). 